\title{
Rapid review of the existing COVID-19 Case Definitions: A Bayesian Approach model to COVID- 19 Case Definitions: A Research Article
}

\section{Emad Karimian Rad}

Iran University of Medical Sciences https://orcid.org/0000-0002-7629-7651

Shahram Yazdani ( $\nabla$ shahram_yazdani@hotmail.com)

National Agency for Strategic Research in Medical Education

Zeynab Foroughi

Iran University of Medical Sciences

Ali-Akbar Haghdoost

Deputy for Education, Ministry of Health and Medical Education

Hadi Jabali

Iran University of Medical Sciences

Alireza Hajikhani

Shahid Beheshti University of Medical Sciences School of Medicine

Maryam Hoseini Abardeh

National Agency for Strategic Research in Medical Education

\section{Research Article}

Keywords: case definitions, case definition and surveillance, Corona-virus, Coronavirus, COVID-19, novel coronavirus, novel coronavirus disease, 2019-nCoV, coronavirus disease, Severe acute respiratory syndrome coronavirus 2 and SARS-CoV-2

Posted Date: May 6th, 2020

DOl: https://doi.org/10.21203/rs.3.rs-26337/v1

License: (c) (i) This work is licensed under a Creative Commons Attribution 4.0 International License. Read Full License 
TITLE: Rapid review of the existing COVID-19 Case Definitions: A Bayesian Approach model to COVID-19 Case Definitions: A Research Article

Emad Karimian Rad, Shahram Yazdani, Zeynab Foroughi, Ali-Akbar Haghdoost, Hadi Jabali, Alireza Hajikhani, Maryam Hoseini Abardeh

Emad Karimian Rad (first author)

Department of Health Service Management, School of Health Management and Information Sciences, Iran University of Medical Sciences, Tehran, Iran.

Email:emadkrad@gmail.com

Shahram Yazdani (corresponding author)

Research Deputy, National Agency for Strategic Research in Medical Education, Tehran, Iran.

Email: shahram_yazdani@hotmail.com

\section{Zeynab Foroughi}

Department of Health Service Management, School of Health Management and Information Sciences, Iran University of Medical Sciences, Tehran, Iran.

Email: foroughi.z@tak.iums.ac.ir

\section{Ali-Akbar Haghdoost}

Deputy for Education, Ministry of Health and Medical Education, Tehran, Iran.

Email: ahaghdoost@gmail.com

\section{Hadi Jabali}

Department of Health Service Management, School of Health Management and Information Sciences, Iran University of Medical Sciences, Tehran, Iran.

Email: Jabali.h@tak.iums.ac.ir

\section{Alireza Hajikhani}


Faculty of Medicine, Shahid Beheshti University of Medical Sciences, Tehran, Iran.

Email: alirezahajikhani@gmail.com

\section{Maryam Hoseini Abardeh}

National Agency for Strategic Research in Medical Education, Tehran. Iran,

Email: hoseiniabardeh.maryam@gmail.com

\section{Background}

Since December 2019, the novel coronavirus disease (COVID-19) has rapidly spread around the world leading to a pandemic with more than 3,000,000 infected people and more than 200,000 death. Several case definitions have been released and revised by countries and organizations. However, collectivization of case definitions has not been fully investigated.

\section{Methods}

In this study, we rapidly reviewed existing COVID-19 case definitions, finally a dynamic case definition algorithm was provided by using Bayesian theorem models of diagnosis.

\section{Results}

Our results showed categorization as suspected, probable, and confirmed cases, is used in majority of case definitions. Furthermore, the criteria for suspected cases and laboratory testing priority was a point of argument. Due to pandemic situation and resource limitation, diagnostic tests were rationed and mainly administered to a selected population, thus it was shown that the fraction of positive test results does not reflect the total infection rate of the population. Case definitions for COVID-19 is changing as we learn more about the disease. RT-PCR and CT Scan of lung seem to be beneficial in COVID-19 diagnosis and combing them with epidemiological criteria helps us in better understanding of the disease.

\section{Conclusion}


Based on our results, in the current case definitions, only symptomatic patients categorized and tested as a susceptible case. While the majority of COVID-19 cases are asymptomatic carriers of the disease, thus making the prevention more challenging. Dynamic statistical models can provide new insights into surveillance systems.

\section{Keywords:}

case definitions, case definition and surveillance, Corona-virus, Coronavirus, COVID-19, novel coronavirus, novel coronavirus disease, 2019-nCoV, coronavirus disease, Severe acute respiratory syndrome coronavirus 2 and SARS-CoV-2

\section{Background}

On December 31, 2019, China announced the emergence of a new type of coronavirus which later on January 12, 2020, was named COVID-19 by WHO (World Health Organization). COVID-19 rapidly spread across China and other countries around the world, which lead the World Health Organization to declare COVID-19 as a pandemic on March 11, 2020(1).As of 28 April 2020, 2,954,222 confirmed cases, with 202,597 deaths of COVID-19 have been reported to World Health Organization.

COVID-19 infection manifestation varies from being asymptomatic to mild or severe pneumonia. Monitoring the number of coronavirus infections is an essential task in processing the provision of an appropriate epidemiological response.(2) Simple counting the number of coronavirus cases can be misleading due to difficulties with patient access and performing laboratory tests. Therefore, evidence suggests a critical need for robust surveillance systems to actively monitor people for disease infection. The International Health Regulation (IHR) defines surveillance as "the systematic ongoing collection, collation, and analysis of data for public health purposes and the timely dissemination of public health information for assessment and public health response as necessary". (3) 
One of the first steps in response to the novel Coronavirus pandemic in several countries was strengthening of surveillance systems for identifying different cases. In this regard, countries enhanced their laboratory systems and defined cases that need the test. (4).

Case definitions have been recognized as one of the most important components of public health surveillance systems.(5) A case definition is a written statement of findings that are both necessary and sufficient to classify an individual as having a disease. More commonly, however, the determination of whether an individual has a disease is left to the expert judgment of a clinician (6) Case definitions assure the comparability and consistency of surveillance data. The World Health Organization considers the use of case definitions essential to make surveillance data comparable between countries. Defining cases transparently is essential for effectively assessing an outbreak event. The usage of common case definition allows standardization of cases and provide comparisons inside outbreak and probably between outbreaks over time and in different geographical areas, which includes defining and setting criteria for common demographic characteristics of Patients, location (specific geographic area), time (outbreak-related time period), and clinical features (clinical symptoms such as fever and cough)(7)

Case definitions can be based on Boolean logical statements which consist of using necessary and sufficient clinical findings with "AND" and "OR" operations. Also, it can be based on probabilistic statements that are based on conditional probabilities. In this approach, based on probability thresholds diagnosis is categorized as confirmed, probable, or suspected. For example, If $\mathrm{P}$ (Disease $\mid$ Data) $>0.99$ case is categorized as confirmed case.(6) Therefore this study suggests that it is more likely that a probabilistic approach can be more useful in COVID-19 case definitions.

\section{Methods}

This study was conducted in two phases. In the first phase, a rapid review of existing literature for case definitions and review studies on the epidemiology of COVID-19 disease was conducted to detect different components, criteria, and categorizations of case definitions by researchers. In the second 
phase, a dynamic case definition algorithm was applied using the Bayesian theorem models of diagnosis to represent case definitions.

\section{First phase: Rapid literature review}

\section{Search and Databases}

For the rapid review of existing case definitions, case definition and surveillance keywords, and similar words along with Corona-virus, Coronavirus, COVID-19, novel coronavirus, novel coronavirus disease, 2019-nCoV, coronavirus disease, Severe acute respiratory syndrome coronavirus 2 and SARSCoV-2 were used in PubMed database and Google scholar database. Also, to gain a comprehensive definition of Gregg's definition, including the person, place, time, and clinical features of the new coronavirus disease, rapid review on epidemiological review studies of the disease published from December 31, 2019, to March 26, 2020, was performed. For this purpose, the keywords Epidemiological characteristic, epidemiology, clinical features, incubation period, clinical description, clinical findings, clinical course, symptoms, and surveillance were used along with various new coronavirus names to search Embase, PubMed and Google scholar databases.

Identified studies were screened by relevance of title and abstract and then full texts screened by inclusion and exclusion criteria.

\section{Inclusion and exclusion criteria}

Regarding case definitions, all types of evidence including different countries' and organizations' reports that provided definitions of COVID-19 cases were included.

About the review of epidemiological studies, among the identified studies in databases, Englishlanguage review articles that addressed the epidemiology of the new coronavirus disease, including clinical features, transmission methods, and demographic characteristics of COVID-19 cases were included and the Studies that addressed the epidemiology of other coronaviruses or did not provide the required information excluded. Two researchers searched databases independently and two sets of 
studies compared and disagreements regarding the included studies resolved with discussion and third researcher's opinion.

\section{Data extraction}

Based on Gregg's framework, all the information related to symptoms and diagnostic tests including clinical features, disease-related periods (incubation period, etc.), places of the disease transmission, Demographic and physical characteristics of patients, were extracted.

\section{Second Phase: Using the Bayesian Approach}

In this study, we use Bayesian approach to create a dynamic case definition, with following this purpose we combine disease likelihood (Data) including symptom, sign and findings of a patient with a pretest probability distribution of disease (Disease). Consequently, the probability of disease is P (Disease | Data). Variables in Bayesian approach are diagnosis and findings which use for diagnosing of disease, it includes all findings which have high specificity to rule in and high sensitivity to rule out in diagnosis. $(8,9)$

This approach carried out in three stages: in the first stage, the aim was to generate the pretest probability using the method of objective probability estimates. In the second stage, the aim was to gather more information about the COVID-19 disease and its diagnosis so we focused on the studies relating to diagnostic tests on COVID-19 cases. In the third stage, the aim was to modify and update the covid-19 case definition by using the results of previous stages. In this stage, we tried to update the initial probability estimation. The input for calculating the posttest probability of COVID-19 were the likelihood ratio calculated with results of diagnostic tests and the Pretest probability based on the existing knowledge.

\section{Results}


The majority of case definitions categorized as suspected, probable, and confirmed cases. To define suspected cases different organizations combined clinical criteria, which include most common symptoms of COVID-19 patients (i.e. fever, cough, shortness of breath...), with epidemiological criteria which include a history of travel to or residence in a location with reported community transmission of disease and a history of close contact with a confirmed case. In Taiwan, case definition classification divided into reporting, probable, and confirmed cases. Patients with one of the clinical criteria and epidemiological criteria or one laboratory criteria classified as reporting cases. In New Zealand, suspected cases prioritized based on having some criteria which they or one or more of their household/bubble have for the test. Communicable Diseases Network in Australia (CDNA) divided suspected cases to Very high risk, High-risk setting, Moderate risk, and Background risk based on their epidemiologic criteria. The parameters of the definition are not conclusive in the literature on the coronavirus because of the lack of available data. Data on prevalence, for example, is obtained from RT-PCR positive results of testing for the coronavirus, and furthermore, tests have been rationed and almost entirely have been administered to a selected population mainly patients presenting with severe symptoms or vulnerable individuals. Thus, the fraction of positive test results does not reflect the total infection rate of the population. Although these tests were made available during the outbreak, their sensitivity and specificity were unknown because there are no "gold standard" laboratory or clinical definitions for the diagnosis of COVID-19. The disease definitions developed by the World Health Organization (WHO), the US Centers for Disease Control and Prevention, European Centre for Disease Prevention and Control (ECDC) care are broadly inclusive and nonspecific. Table 1 shows case definitions by different organizations and countries.

Also, data extracted from 10 epidemiological review studies in four dimensions of person, time, place and clinical features showed that an important parameter is the asymptomatic individual rate (the fraction of the infected who are not tested under current guidelines) therefore estimation lacks in the literature because tests for the coronavirus have been targeted at the sick and vulnerable. However, number of studies suggest that it could be estimated by a general screening of the population. 
Furthermore, various studies showed the susceptibility and vulnerability of people to disease based on a variety of underlying conditions such as old age, hypertension, diabetes, cardiovascular diseases, immunosuppressive diseases, and male gender. Table 2 summarizes the reviewed studies and their data.

Following is our finding based on the literature review and using the Bayesian method.

The First stage (Pretest probability): By reviewing existing studies the pretest probability was generated based on three criteria:

1- The presence or absence of a history of close contact with the COVID-19 case, based on the result of the literature review, in this study close contact include:

- Living with a confirmed COVID-19 case

- Direct contact without protective equipment or contact with bodily fluids of a confirmed covid-19 case individual

- Direct or face to face contact with a confirmed COVID-19 case individual regardless of time

- Being less than two meters away from a confirmed COVID-19 case individual for more than 15 minutes

- Referral and visit to a medical center where people with covid-19 have been admitted.

- Health care staff dealing with COVID-19

- Being otherwise advised by a public health agency that contact with a confirmed case has occurred

2- The presence or absence of typical clinical syndrome which respectively includes: Fever, dry cough, myalgia, fatigue, and normal or decreased white blood cells and decreased lymphocytes at the onset of the disease 
3- History of Living in or traveling to an area with a high incidence or prevalence of COVID-19 case (an area that accounts for more than $30 \%$ of community infections)

The Second stage (Likelihood Ratio): After reviewing the studies, evidence suggested that two medical tests seem to be beneficial in covid-19 diagnosis which were CT-Scan of lung and RT-PCR. Based on this result these two tests could be a key parameter to achieve a better understanding of COVID-19 case definition. To measure the validity of these two tests, several studies were identified and reviewed leading to determining their specificity $(\mathrm{Sp})$ and sensitivity $(\mathrm{Sn})$, consequently the "Likelihood ratio" was calculated for CT-Scan and RT-PCR. The mentioned tests likelihood ratio was figured in the following terms:

\section{CT scan of the lung:}

- $\quad$ positive result $(+)$

- Negative result (-)

- Not-performed (NP) or inconclusive results

\section{RT-PCR test}

- positive result (+)

- Negative result (-)

- Not-performed (NP)

Post-test probability was calculated as follows: 


\begin{tabular}{|c|c|c|c|c|}
\hline & $\mathrm{Sn}$ & $\mathrm{Sp}$ & $\mathrm{LR}+$ & $\mathrm{LR}-$ \\
\hline $\mathrm{CT}$ & 66 & 80 & 3.3 & 0.41 \\
\hline RT-PCR & 0.6 & 99.6 & 150 & 0.4 \\
\hline
\end{tabular}

$$
\begin{aligned}
& \text { pretest odds }=\frac{\text { pretest probability }}{1-\text { pretest probability }} \\
& \text { posttest odds }=\text { pretest odds } \times \text { likelihood ratio } \\
& \text { Posttest probability }=\text { Posttest odds } / \text { (Posttest odds }+1 \text { ) }
\end{aligned}
$$

\begin{tabular}{|c|c|c|c|c|c|c|c|c|c|c|c|c|c|c|c|}
\hline & Sn & Sp & LR+ & LR- & & CT & + & + & - & - & + & - & NP & NP & NP \\
\hline CT & 66 & 80 & 3.3 & 0.41 & & & & & & & & & & & \\
\hline RT-PCR & 0.6 & 99.6 & 150 & 0.4 & & & + & - & + & - & $\mathrm{NP}$ & NP & + & - & $\mathrm{NP}$ \\
\hline & & & & & & & $\downarrow$ & $\downarrow$ & $\downarrow$ & $\downarrow$ & $\downarrow$ & $\downarrow$ & $\downarrow$ & $\downarrow$ & $\downarrow$ \\
\hline $\begin{array}{c}\text { Close Contact } \\
\mathrm{Hx}\end{array}$ & $\begin{array}{r}\text { Typical } \\
\text { Synd }\end{array}$ & $\begin{array}{l}\text { Clinical } \\
\text { ome }\end{array}$ & $\begin{array}{l}\text { Resic } \\
\text { Trav }\end{array}$ & $\begin{array}{l}\text { nce / } \\
\text { Risk }\end{array}$ & & & 495 & 1.32 & 61.5 & 0.16 & 3.3 & 0.41 & 150 & 0.4 & 1 \\
\hline \multirow{4}{*}{+} & \multirow{2}{*}{\multicolumn{2}{|c|}{+}} & \multicolumn{2}{|c|}{+} & $\rightarrow$ & 0.8 & 0.999 & 0.84 & 0.996 & 0.39 & 0.93 & 0.63 & 0.998 & 0.62 & 0.8 \\
\hline & & & \multicolumn{2}{|c|}{ - } & $\rightarrow$ & 0.7 & 0.999 & 0.76 & 0.993 & 0.27 & 0.89 & 0.49 & 0.997 & 0.48 & 0.7 \\
\hline & \multirow{2}{*}{\multicolumn{2}{|c|}{ - }} & \multicolumn{2}{|c|}{+} & $\rightarrow$ & 0.4 & 0.996 & 0.47 & 0.976 & 0.1 & 0.69 & 0.21 & 0.99 & 0.21 & 0.4 \\
\hline & & & \multicolumn{2}{|c|}{ - } & $\rightarrow$ & 0.3 & 0.985 & 0.36 & 0.964 & 0.06 & 0.59 & 0.15 & 0.984 & 0.15 & 0.3 \\
\hline \multirow{4}{*}{ - } & \multirow{2}{*}{\multicolumn{2}{|c|}{+}} & \multicolumn{2}{|c|}{+} & $\rightarrow$ & 0.35 & 0.996 & 0.42 & 0.97 & 0.08 & 0.64 & 0.18 & 0.988 & 0.18 & 0.35 \\
\hline & & & \multicolumn{2}{|c|}{ - } & $\rightarrow$ & 0.2 & 0.991 & 0.25 & 0.94 & 0.04 & 0.45 & 0.09 & 0.97 & 0.09 & 0.2 \\
\hline & \multirow{2}{*}{\multicolumn{2}{|c|}{ - }} & \multicolumn{2}{|c|}{+} & $\rightarrow$ & 0.15 & 0.98 & 0.19 & 0.92 & 0.03 & 0.37 & 0.07 & 0.96 & 0.06 & 0.15 \\
\hline & & & \multicolumn{2}{|c|}{ - } & $\rightarrow$ & 0.1 & 0.98 & 0.13 & 0.87 & 0.02 & 0.27 & 0.05 & 0.94 & 0.04 & 0.1 \\
\hline
\end{tabular}

Accordingly, the simple clinical decision rule in Figure 1 will be used to determine the probability of COVID-19 infection.

Figure 1 probability of COVID-19 infection.

The Third Stage (posttest probability): This stage aimed to modify and update the covid-19 case definition by using the results of previous stages. In this stage, we tried to update the initial probability estimation. The likelihood ratio calculated with Diagnostic test results and the Pretest probability based on the existing knowledge was the input for calculating the posttest probability of covid-19. 
Consequently, the probability of the covid-19 disease infection is classified into the following four categories:

- Confirmed cases (over $80 \%$ probability)

- Probable cases (probability between $40 \%$ and $79 \%$ )

- Suspected cases (probable between 10\% and 39\%)

- Improbable cases (less than $10 \%$ probability)

\begin{tabular}{|c|c|c|c|c|}
\hline & Sn & Sp & LR+ & LR- \\
\hline CT & 66 & 80 & 3.3 & 0.41 \\
\hline RT-PCR & 0.6 & 99.6 & 150 & 0.4 \\
\hline
\end{tabular}

\begin{tabular}{c|c|c|c|c|c|c|c|c|c|}
\hline $\mathrm{CT}$ & + & + & - & - & + & - & $\mathrm{NP}$ & $\mathrm{NP}$ & $\mathrm{NP}$ \\
\hline RT-PCR & + & - & + & - & $\mathrm{NP}$ & $\mathrm{NP}$ & + & - & $\mathrm{NP}$ \\
\hline
\end{tabular}

\begin{tabular}{|c|c|c|}
\hline $\begin{array}{c}\text { Close Contact } \\
\mathrm{Hx}\end{array}$ & $\begin{array}{c}\text { Typical Clinical } \\
\text { Syndrome }\end{array}$ & $\begin{array}{c}\text { Residence / } \\
\text { Travel Risk }\end{array}$ \\
\hline \multirow{4}{*}{+} & + & + \\
\cline { 3 - 3 } & \multirow{2}{*}{+} & - \\
\cline { 3 - 3 } & & + \\
\hline \multirow{4}{*}{-} & + & + \\
\cline { 3 - 3 } & + & + \\
\cline { 3 - 3 } & & + \\
\cline { 3 - 3 } & & + \\
\hline
\end{tabular}

\begin{tabular}{|c|c|c|c|c|c|c|c|c|c|}
\hline $\begin{array}{l}\text { Pretest } \\
\text { Probabilitity }\end{array}$ & 495 & 1.32 & 61.5 & 0.16 & 3.3 & 0.41 & 150 & 0.4 & 1 \\
\hline 0.8 & 0.999 & 0.84 & 0.996 & 0.39 & 0.93 & 0.63 & 0.998 & 0.62 & 0.8 \\
\hline 0.7 & 0.999 & 0.76 & 0.993 & 0.27 & 0.89 & 0.49 & 0.997 & 0.48 & 0.7 \\
\hline 0.4 & 0.996 & 0.47 & 0.976 & 0.1 & 0.69 & 0.21 & 0.99 & 0.21 & 0.4 \\
\hline 0.3 & 0.985 & 0.36 & 0.964 & 0.06 & 0.59 & 0.15 & 0.984 & 0.15 & 0.3 \\
\hline 0.35 & 0.996 & 0.42 & 0.97 & 0.08 & 0.64 & 0.18 & 0.988 & 0.18 & 0.35 \\
\hline 0.2 & 0.991 & 0.25 & 0.94 & 0.04 & 0.45 & 0.09 & 0.97 & 0.09 & 0.2 \\
\hline 0.15 & 0.98 & 0.19 & 0.92 & 0.03 & 0.37 & 0.07 & 0.96 & 0.06 & 0.15 \\
\hline 0.1 & 0.98 & 0.13 & 0.87 & 0.02 & 0.27 & 0.05 & 0.94 & 0.04 & 0.1 \\
\hline & \multicolumn{9}{|c|}{ Post-test Probability } \\
\hline & \multicolumn{2}{|c|}{ Confirmed } & \multicolumn{2}{|c|}{ Probable } & \multicolumn{3}{|c|}{ Suspected } & \multicolumn{2}{|c|}{ Improbable } \\
\hline
\end{tabular}

Figure 2 classification of the probability of the covid-19 disease infection

\section{Discussion and conclusion:}

Until now, there is no definitive treatment for COVID-19, consequently, inevitably a robust surveillance system is necessary for monitoring of infected people. (12) Furthermore, in order to achieve early detection and isolation of COVID-19 cases, careful assessments within the surveillance system are 
necessary at primary health care centers (13). An appropriate case definition can contribute to the efficient identification of infected patients.(14) Health authorities in different countries should revise their case definitions based on available epidemiological information .(15)

In different COVID-19 case definitions by countries and organizations clinical criteria including most common symptoms of the disease and epidemiological criteria including the history of travel or residence in a location with report of community transmission of disease and history of close contact with a confirmed case were used. Based on our results, in the current case definitions, only symptomatic patients categorized and tested as a susceptible case. Although studies showed the majority of people are asymptomatic carriers of the disease. It still remains a huge challenge in prevention of the disease. (16) Especially this challenge is prevalent among people under 15 and pregnant women. The results of a study on February 17, 2020, suggested among 1732 traveler, 189 were asymptomatic patients whose tests for new coronavirus were positive. Based on the result of this study we should consider people with a history of close contact and traveling for the affected regions for performing tests(17).

We use Bayesian approach for creating our case definition. The first use of the Bayes approach for disease diagnosis was by Homer Warner in 1961. (10) This version of Bayes' formula is in fact the mathematical equivalent of clinical diagnostic reasoning. We combine what we believe before doing the test with what we learn from the test to derive what we believe after doing the test. It makes use of the concepts of odds and likelihood ratio, which we define at this point. It also forms the basis for a simple pocket nomogram for rapidly working out post-test probabilities.

Based on our framework the possibility of a person from the affected region with typical clinical syndromes, normal chest CT, without a history of close contact, and in the absence of PCR test result, for COVID-19 is $18 \%$ and categorized as a suspected case. 


\begin{tabular}{|c|c|c|c|c|c|c|c|c|c|c|c|c|c|c|c|}
\hline & Sn & Sp & LR+ & LR- & & CT & + & + & - & - & + & - & NP & NP & NP \\
\hline CT & 66 & 80 & 3.3 & 0.41 & & \multirow{2}{*}{ RT-PCR } & \multirow{2}{*}{+} & \multirow{2}{*}{-} & \multirow{2}{*}{+} & \multirow{2}{*}{-} & \multirow{2}{*}{ NP } & \multirow{2}{*}{ NP } & \multirow{2}{*}{+} & \multirow{2}{*}{-} & \multirow{2}{*}{ NP } \\
\hline RT-PCR & 0.6 & 99.6 & 150 & 0.4 & & & & & & & & & & & \\
\hline & & & & & & & $\downarrow$ & $\downarrow$ & $\downarrow$ & $\downarrow$ & $\downarrow$ & $\downarrow$ & $\downarrow$ & $\downarrow$ & $\downarrow$ \\
\hline $\begin{array}{c}\text { Close Contact } \\
\mathrm{Hx}\end{array}$ & $\begin{array}{r}\text { Typical } \\
\text { Sync }\end{array}$ & $\begin{array}{l}\text { Clinical } \\
\text { ome }\end{array}$ & $\begin{array}{l}\text { Resi } \\
\text { Trav }\end{array}$ & $\begin{array}{l}\text { nce / } \\
\text { Risk }\end{array}$ & & $\begin{array}{l}\text { Pretest Likelihood } \\
\text { Probability }\end{array}$ & 495 & 1.32 & 61.5 & 0.16 & 3.3 & 0.41 & 150 & 0.4 & 1 \\
\hline \multirow{4}{*}{+} & \multirow{2}{*}{\multicolumn{2}{|c|}{+}} & \multicolumn{2}{|c|}{+} & $\rightarrow$ & 0.8 & 0.999 & 0.84 & 0.996 & 0.39 & 0.93 & 0.63 & 0.998 & 0.62 & 0.8 \\
\hline & & & \multicolumn{2}{|c|}{ - } & $\rightarrow$ & 0.7 & 0.999 & 0.76 & 0.993 & 0.27 & 0.89 & 0.49 & 0.997 & 0.48 & 0.7 \\
\hline & \multirow{2}{*}{\multicolumn{2}{|c|}{ - }} & \multicolumn{2}{|c|}{+} & $\rightarrow$ & 0.4 & 0.996 & 0.47 & 0.976 & 0.1 & 0.69 & 0.21 & 0.99 & 0.21 & 0.4 \\
\hline & & & & & $\rightarrow$ & 0.3 & 0.985 & 0.36 & 0.964 & 0.06 & 0.59 & 0.15 & 0.984 & 0.15 & 0.3 \\
\hline \multirow{4}{*}{-} & \multirow{2}{*}{\multicolumn{2}{|c|}{+}} & \multicolumn{2}{|c|}{+} & $\rightarrow$ & 0.35 & 0.996 & 0.42 & 0.97 & 0.08 & 0.64 & 0.18 & 0.988 & 0.18 & 0.35 \\
\hline & & & \multicolumn{2}{|c|}{ - } & $\rightarrow$ & 0.2 & 0.991 & 0.25 & 0.94 & 0.04 & 0.45 & 0.09 & 0.97 & 0.09 & 0.2 \\
\hline & \multirow{2}{*}{\multicolumn{2}{|c|}{ - }} & \multicolumn{2}{|c|}{+} & $\rightarrow$ & 0.15 & 0.98 & 0.19 & 0.92 & 0.03 & 0.37 & 0.07 & 0.96 & 0.06 & 0.15 \\
\hline & & & \multicolumn{2}{|c|}{ - } & $\rightarrow$ & 0.1 & 0.98 & 0.13 & 0.87 & 0.02 & 0.27 & 0.05 & 0.94 & 0.04 & 0.1 \\
\hline
\end{tabular}

Figure 3: Post-test probability for CT ( - ) , RT-PCR (NP), Close Contact ( - ), Symptom ( + ), Location ( + )

Also, the possibility of a person from affected regions, without a history of close contact and disease symptoms, with normal chest CT and positive PCR for COVID-19 is $76 \%$ and categorized as a probable case.

\begin{tabular}{|c|c|c|c|c|}
\hline & Sn & Sp & LR+ & LR- \\
\hline CT & 66 & 80 & 3.3 & 0.41 \\
\hline RT-PCR & 0.6 & 99.6 & 150 & 0.4 \\
\hline
\end{tabular}$\rightarrow$

\begin{tabular}{c|c|c|c|c|c|c|c|c|c|}
$\mathrm{CT}$ & + & + & - & - & + & - & $\mathrm{NP}$ & $\mathrm{NP}$ & $\mathrm{NP}$ \\
\hline $\mathrm{RT}-\mathrm{PCR}$ & + & - & + & - & $\mathrm{NP}$ & $\mathrm{NP}$ & + & - & $\mathrm{NP}$ \\
\hline
\end{tabular}

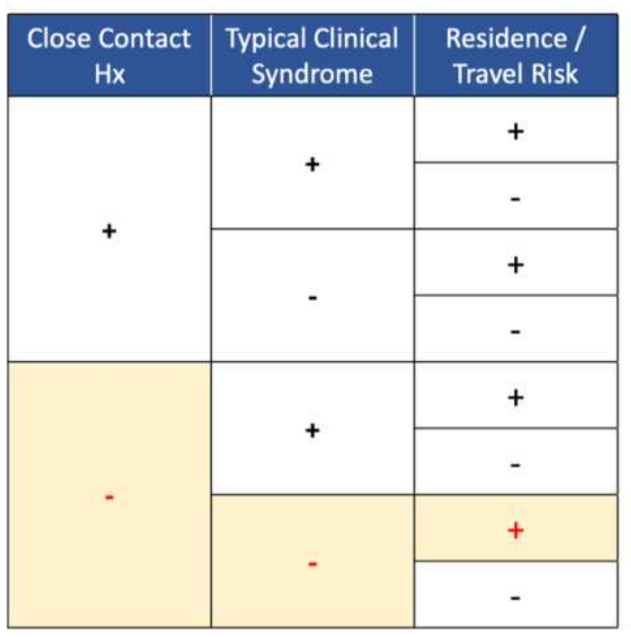

\begin{tabular}{|c|c|c|c|c|c|c|c|c|c|}
\hline $\begin{array}{l}\text { Pretest Likelihood } \\
\text { Probability } \\
\end{array}$ & 495 & 1.32 & 61.5 & 0.16 & 3.3 & 0.41 & 150 & 0.4 & 1 \\
\hline 0.8 & 0.999 & 0.84 & 0.996 & 0.39 & 0.93 & 0.63 & 0.998 & 0.62 & 0.8 \\
\hline 0.7 & 0.999 & 0.76 & 0.993 & 0.27 & 0.89 & 0.49 & 0.997 & 0.48 & 0.7 \\
\hline 0.4 & 0.996 & 0.47 & 0.976 & 0.1 & 0.69 & 0.21 & 0.99 & 0.21 & 0.4 \\
\hline 0.3 & 0.985 & 0.36 & 0.964 & 0.06 & 0.59 & 0.15 & 0.984 & 0.15 & 0.3 \\
\hline 0.35 & 0.996 & 0.42 & 0.97 & 0.08 & 0.64 & 0.18 & 0.988 & 0.18 & 0.35 \\
\hline 0.2 & 0.991 & 0.25 & 0.94 & 0.04 & 0.45 & 0.09 & 0.97 & 0.09 & 0.2 \\
\hline 0.15 & 0.98 & 0.19 & 0.92 & 0.03 & 0.37 & 0.07 & 0.96 & 0.06 & 0.15 \\
\hline 0.1 & 0.98 & 0.13 & 0.87 & 0.02 & 0.27 & 0.05 & 0.94 & 0.04 & 0.1 \\
\hline
\end{tabular}


Figure 4: Post-test probability for CT ( - ), RT-PCR ( + ), Close Contact ( - ), Symptom ( - ), Location ( + )

The possibility of a person from a safe region, with history of close contact, in absence of disease symptoms, without chest CT, and with positive PCR is $98 \%$ and categorized as a confirmed case.

\begin{tabular}{|c|c|c|c|c|}
\hline & Sn & Sp & LR+ & LR- \\
\hline CT & 66 & 80 & 3.3 & 0.41 \\
\hline RT-PCR & 0.6 & 99.6 & 150 & 0.4 \\
\hline
\end{tabular}

\begin{tabular}{|c|c|c|c|c|c|c|c|c|c|}
\hline $\mathrm{CT}$ & + & + & - & - & + & - & $\mathrm{NP}$ & $\mathrm{NP}$ & $\mathrm{NP}$ \\
\hline $\mathrm{RT}-\mathrm{PCR}$ & + & - & + & - & $\mathrm{NP}$ & $\mathrm{NP}$ & + & - & $\mathrm{NP}$ \\
\hline
\end{tabular}

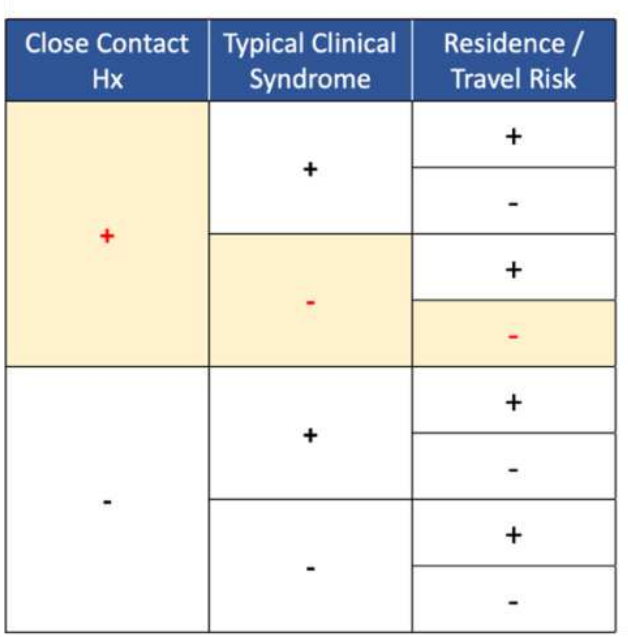

\begin{tabular}{|c|c|c|c|c|c|c|c|c|c|}
\hline $\begin{array}{l}\text { Likelihood } \\
\text { Pretest } \\
\text { Probability }\end{array}$ & 495 & 1.32 & 61.5 & 0.16 & 3.3 & 0.41 & 150 & 0.4 & 1 \\
\hline 0.8 & 0.999 & 0.84 & 0.996 & 0.39 & 0.93 & 0.63 & 0.998 & 0.62 & 0.8 \\
\hline 0.7 & 0.999 & 0.76 & 0.993 & 0.27 & 0.89 & 0.49 & 0.997 & 0.48 & 0.7 \\
\hline 0.4 & 0.996 & 0.47 & 0.976 & 0.1 & 0.69 & 0.21 & 0.99 & 0.21 & 0.4 \\
\hline 0.3 & 0.985 & 0.36 & 0.964 & 0.06 & 0.59 & 0.15 & 0.984 & 0.15 & 0.3 \\
\hline 0.35 & 0.996 & 0.42 & 0.97 & 0.08 & 0.64 & 0.18 & 0.988 & 0.18 & 0.35 \\
\hline 0.2 & 0.991 & 0.25 & 0.94 & 0.04 & 0.45 & 0.09 & 0.97 & 0.09 & 0.2 \\
\hline 0.15 & 0.98 & 0.19 & 0.92 & 0.03 & 0.37 & 0.07 & 0.96 & 0.06 & 0.15 \\
\hline 0.1 & 0.98 & 0.13 & 0.87 & 0.02 & 0.27 & 0.05 & 0.94 & 0.04 & 0.1 \\
\hline
\end{tabular}

Figure 5: Post-test probability for CT ( NP ), RT-PCR ( + ), Close Contact (+ ), Symptom ( - ), Location ( - )

Consequently, the Bayesian approach has several advantages in confronting the challenges for covid19 case definition, one of them is multiple diagnostic tests with multiple categories, and the other one is the independency of the diagnostic tests, which by using the Bayesian approach this challenges wares.

\section{Study Limitation}

In this study we highlighted the rapidly changing trend of COVID-19 case definitions, therefore we didn't consider the risk of bias in existing case definitions. Also due to dynamicity of the provided model the variables may change for different countries or situations. For future studies developing 
Machine Learning algorithms, particularly deep learning algorithms could adapt and manage the mentioned limitations.

\section{Abbreviations}

WHO: World Health Organization

CDC: Centers for Disease Control and Prevention

ECDC: European Centre for Disease Prevention and Control

SARS-CoV-2: Novel severe acute respiratory syndrome coronavirus

COVID-19: Coronavirus disease 2019

RT-PCR: Reverse transcription polymerase chain reaction

CT: Computed tomography

IHR: The International Health Regulation

CDNA: Communicable Diseases Network in Australia

SP: Specificity

SN: Sensitivity

LR: Likelihood Ratio

Ethics declarations

Ethics approval and consent to participate

Not applicable

\section{Consent for publication}

Not applicable

\section{Competing interests}

The authors declare that they have no competing interests.

\section{Availability of data and materials}


The dataset supporting the conclusions of this article is included as an Additional file table.

\section{Contributions}

Sh.Y, contributed in study design, designed the methodology and performed statistical analysis, developed the dynamic model, prepared the figures.

E.KR, contributed in study design, guided the methodology, conceived the study, wrote the first manuscript, wrote, restructured and revised the final manuscript, was responsible for search strategy, performed the literature search.

Z.F assisted in revision of the manuscript, wrote the first draft, was responsible for article screening against inclusion criteria, and charting the data. prepared the figures, assisted in development of final manuscript.

Aa.H contributed in conceptualization of the study.

H.J contributed in intellectual development of manuscript and modified the paper.

A.H revised the manuscript critically.

M.HA edited the manuscript, assisted in restructuring of the manuscript.

\section{Corresponding author}

Correspondence to Shahram Yazdani

\section{Acknowledgements}

The authors wish to express their thanks for the financial support of "National Agency for Strategic Research in Medical Education" in this project.

\section{Funding}

This study was funded by National Agency for Strategic Research in Medical Education (NASR), Tehran, Iran.

\section{References}

1. Organization WH. Coronavirus disease 2019 ( COVID-19): situation report, 51. 2020. 
2. Lipsitch M, Swerdlow DL, Finelli L. Defining the Epidemiology of Covid-19-Studies Needed. New England Journal of Medicine. 2020.

3. French M, Monahan T. Dis-ease Surveillance: How Might Surveillance Studies Address COVID-19? Surveillance \& Society. 2020;18(1):1-11.

4. Legido-Quigley H, Asgari N, Teo YY, Leung GM, Oshitani H, Fukuda K, et al. Are highperforming health systems resilient against the COVID-19 epidemic? The Lancet. 2020;395(10227):848-50.

5. Krause G, Brodhun B, Altmann D, Claus H, Benzler J. Reliability of case definitions for public health surveillance assessed by Round-Robin test methodology. BMC Public Health. 2006;6(1):129.

6. Tsui F, Wagner M, Cooper G, Que J, Harkema H, Dowling J, et al. Probabilistic case detection for disease surveillance using data in electronic medical records. Online J Public Health Inform. 2011;3(3).

7. Gregg M. Field epidemiology. 2002. New York, Oxford University Press Incorporated.

8. Medow MA, Lucey CR. A qualitative approach to Bayes' theorem. Evid Based Med. 2011;16(6):163-7.

9. Shortliffe EH, Cimino JJ. Biomedical informatics: Springer; 2006.

10. Warner HR, Toronto AF, Veasey LG, Stephenson R. A mathematical approach to medical diagnosis. Application to congenital heart disease. Jama. 1961;177:177-83. 
11. Mnatsakanyan ZR, Burkom HS, Coberly JS, Lombardo JS. Bayesian information fusion networks for biosurveillance applications. J Am Med Inform Assoc. 2009;16(6):855-63.

12. Peeri NC, Shrestha N, Rahman MS, Zaki R, Tan Z, Bibi S, et al. The SARS, MERS and novel coronavirus (COVID-19) epidemics, the newest and biggest global health threats: what lessons have we learned? International journal of epidemiology. 2020.

13. Lake MA. What we know so far: COVID-19 current clinical knowledge and research. Clinical Medicine. 2020;20(2):124.

14. Tsang TK, Wu P, Lin YLY, Lau E, Leung GM, Cowling BJ. Impact of changing case definitions for COVID-19 on the epidemic curve and transmission parameters in mainland China. medRxiv. 2020.

15. Ryu S, Chun BC, of Epidemiology KS. An interim review of the epidemiological characteristics of 2019 novel coronavirus. Epidemiology and Health. 2020;42.

16. Wang $Y$, Wang $Y$, Chen $Y$, Qin $Q$. Unique epidemiological and clinical features of the emerging 2019 novel coronavirus pneumonia (COVID-19) implicate special control measures. Journal of Medical Virology. 2020.

17. Hu Z, Song C, Xu C, Jin G, Chen Y, Xu X, et al. Clinical characteristics of 24 asymptomatic infections with COVID-19 screened among close contacts in Nanjing, China. Science China Life Sciences. 2020:1-6.

18. Organization WH. Global surveillance for human infection with coronavirus disease (COVID-19). World Health Organization, Geneva Available via https://www who 
int/publications-detail/global-surveillance-for-human-infection-with-novel-coronavirus(2019-ncov) Accessed. 2020;27.

19. Huang Y-C, Lee P-I, Hsueh P-R. Evolving reporting criteria of COVID-19 in Taiwan during the epidemic. Journal of Microbiology, Immunology and Infection. 2020.

20. Case Definition - Novel Coronavirus (COVID-19). City of Torento2020. p. https://www.toronto.ca/community-people/health-wellness-care/information-forhealthcare-professionals/communicable-disease-info-for-health-professionals/novelcoronavirus-covid-19-information-for-health-professionals/.

21. Adhikari SP, Meng S, Wu Y-J, Mao Y-P, Ye R-X, Wang Q-Z, et al. Epidemiology, causes, clinical manifestation and diagnosis, prevention and control of coronavirus disease (COVID19) during the early outbreak period: a scoping review. Infectious Diseases of Poverty. 2020;9(1):1-12.

22. Rodriguez-Morales AJ, Cardona-Ospina JA, Gutiérrez-Ocampo E, Villamizar-Peña R, Holguin-Rivera Y, Escalera-Antezana JP, et al. Clinical, laboratory and imaging features of COVID-19: A systematic review and meta-analysis. Travel Medicine and Infectious Disease. 2020:101623.

23. Mao Y, Lin W, Wen J, Chen G. Clinical and pathological characteristics of 2019 novel coronavirus disease (COVID-19): a systematic reviews.

24. Fang Z, Yi F, Wu K, Lai K, Sun X, Zhong N, et al. Clinical Characteristics of Coronavirus Pneumonia 2019 (COVID-19): An Updated Systematic Review. medRxiv. 2020:2020.03.07.20032573. 
25. Jiang F, Deng L, Zhang L, Cai Y, Cheung CW, Xia Z. Review of the clinical characteristics of coronavirus disease 2019 (COVID-19). Journal of General Internal Medicine. 2020:1-5.

26. Rothan HA, Byrareddy SN. The epidemiology and pathogenesis of coronavirus disease (COVID-19) outbreak. Journal of Autoimmunity. 2020:102433. 
Table 1 COVID-19 Case definitions by different countries and organizations

\begin{tabular}{|c|c|c|c|c|}
\hline $\begin{array}{c}\text { Country/ } \\
\text { Organization }\end{array}$ & Suspected /reporting case of COVID-19 & Probable & confirmed & Other categories \\
\hline $\begin{array}{c}\text { WHO } \\
\text { (20 March } \\
\text { 2020) (18) }\end{array}$ & $\begin{array}{l}\text { Suspect case } \\
\text { A. A patient with acute respiratory illness } \\
\text { (fever and at least one sign/symptom of } \\
\text { respiratory disease, e.g., cough, shortness of } \\
\text { breath), } \\
\text { AND } \\
\text { a history of travel to or residence in a location } \\
\text { reporting community transmission of COVID-19 } \\
\text { disease during the } 14 \text { days prior to symptom } \\
\text { onset; } \\
\text { OR } \\
\text { B. A patient with any acute respiratory illness } \\
\text { AND having been in contact with a } \\
\text { confirmed or probable COVID-19 case (see }\end{array}$ & $\begin{array}{l}\text { Probable case } \\
\text { A. A suspect case for whom } \\
\text { testing for the COVID-19 virus } \\
\text { is inconclusive. } 1 \\
\text { OR } \\
\text { B. A suspect case for whom } \\
\text { testing could not be performed } \\
\text { for any reason }\end{array}$ & $\begin{array}{l}\text { Confirmed case A person with } \\
\text { laboratory confirmation of COVID-19 } \\
\text { infection, irrespective of clinical signs } \\
\text { and symptoms. }\end{array}$ & \\
\hline
\end{tabular}




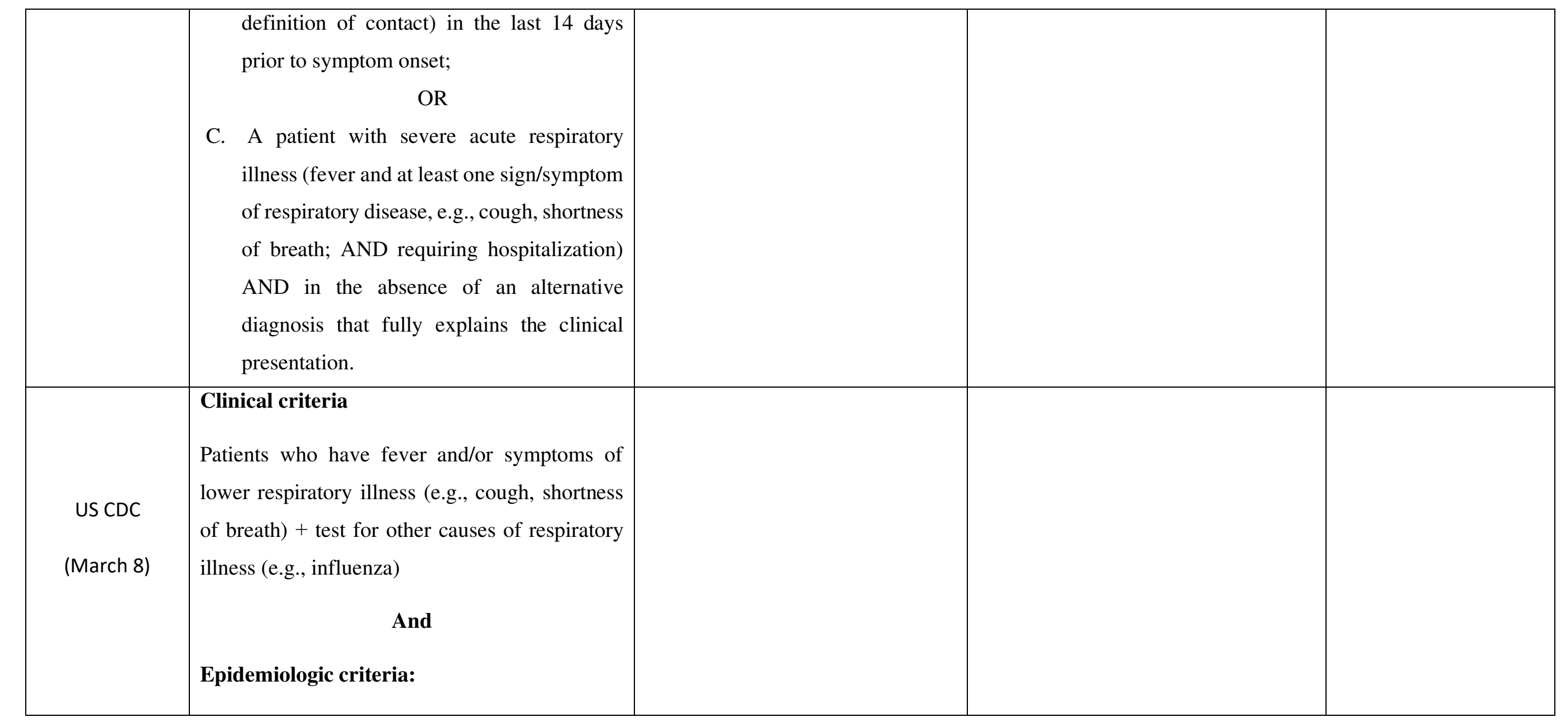




\begin{tabular}{|c|c|c|c|c|}
\hline & $\begin{array}{l}\text { (in the last } 14 \text { days before symptom onset, have } \\
\text { a history of travel from Wuhan City, China, } \\
\text { Hubei Province, and even mainland China } \\
\text { OR } \\
\text { close contact with a person who is under } \\
\text { investigation for COVID-19 while that person } \\
\text { was ill or an ill laboratory-confirmed COVID-19 } \\
\text { patient should be evaluated ) }\end{array}$ & & & \\
\hline Taiwan(19) & $\begin{array}{l}\text { Reporting criteria : } \\
\text { Have any one of the followings: } \\
\text { 1. Fulfilling clinical criteria } 1 \text { or } 2 \text { and } \\
\text { epidemiologic criteria } 1 \text { or } 2 \\
\text { 2.Fulfilling clinical criteria } 2 \text { and epidemiologic } \\
\text { criteria } 3 \text { or } 4 \\
\text { 3. Fulfilling clinical criteria } 3 \\
\text { 4. Fulfilling the laboratory criteria } \\
\text { Clinical criteria }\end{array}$ & $\begin{array}{l}\text { a case satisfied clinical criteria, } \\
\text { though not confirmed by the } \\
\text { laboratory tests, and had intimate } \\
\text { contact with a symptomatic } \\
\text { confirmed case }\end{array}$ & Case satisfied the laboratory criteria & $\begin{array}{l}\text { excluding case: } \\
\text { not satisfying the } \\
\text { former two conditions } \\
\text { (probable or confirmed) }\end{array}$ \\
\hline
\end{tabular}




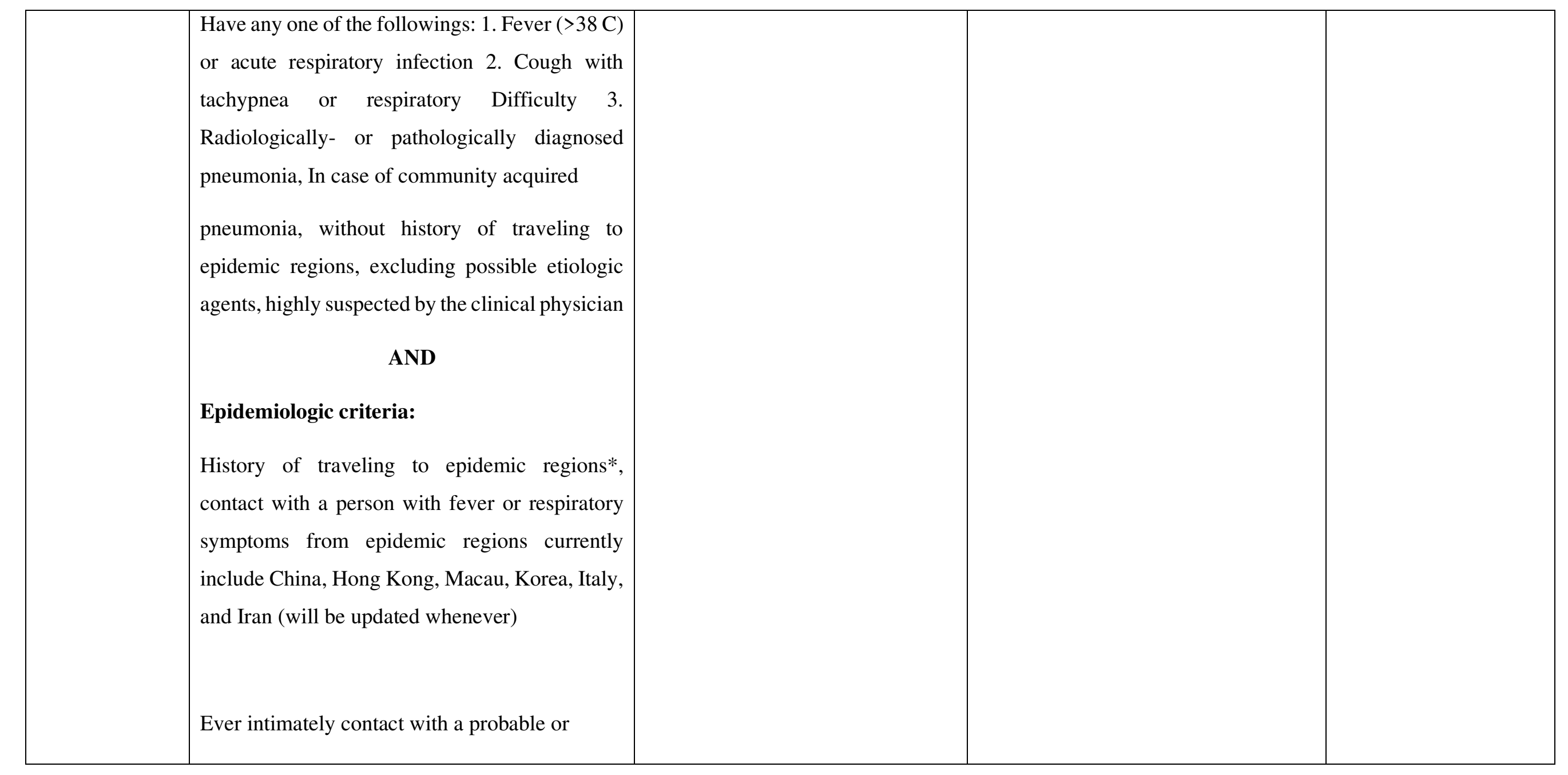




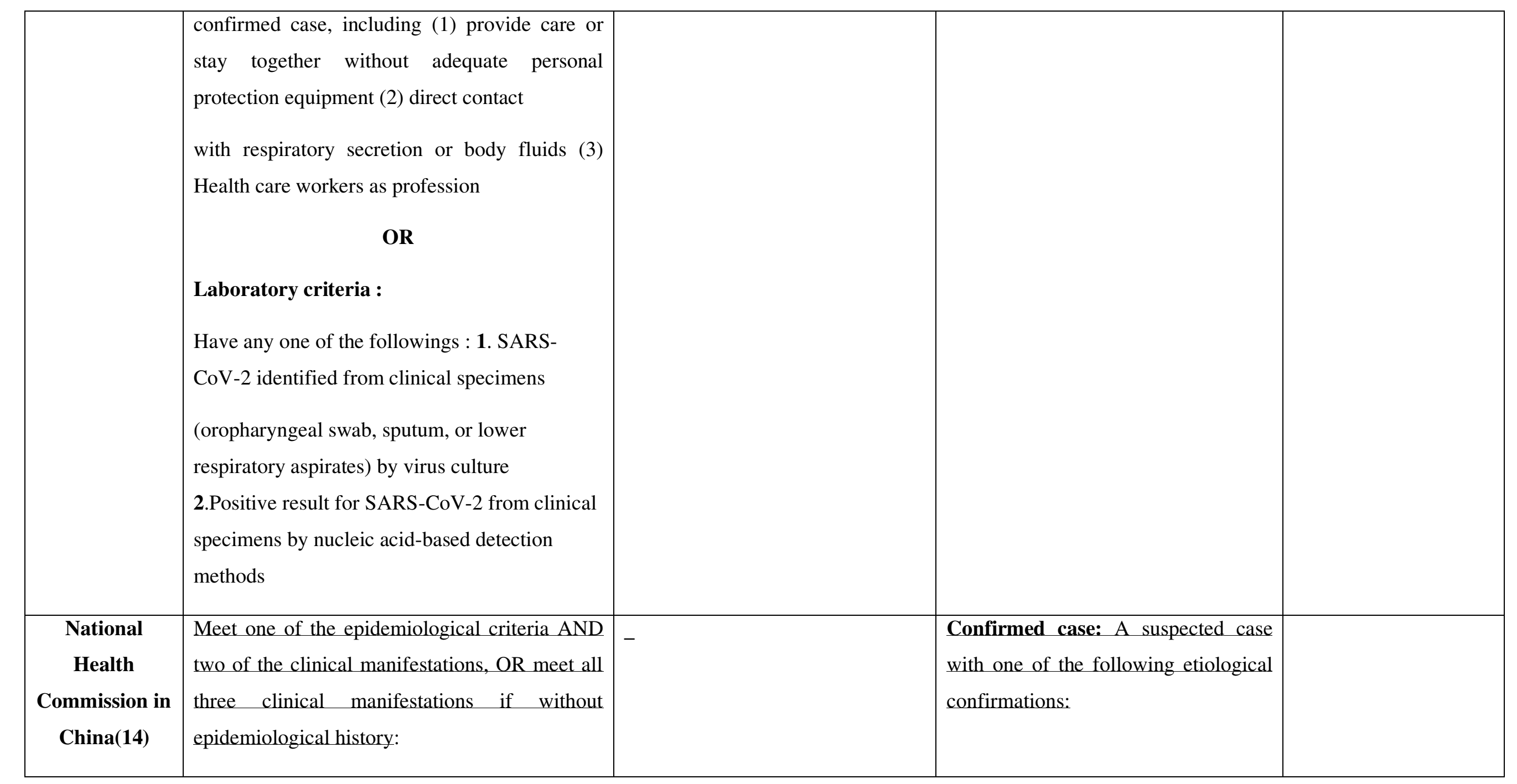




\begin{tabular}{|c|c|c|}
\hline (Mar 3, 2020) & $\begin{array}{l}\text { 1. Epidemiological history: } \\
\text { (1) Travelled to or had lived in Wuhan or the } \\
\text { surrounding areas or other communities with } \\
\text { reported COVID-19 cases within } 14 \text { days before } \\
\text { illness onset; } \\
\text { (2) Contacted with patient(s) infected with } \\
\text { SARS-CoV-2 (positive for SARS-CoV-2 } \\
\text { nucleic acid) within } 14 \text { days before onset; } \\
\text { (3) Contacted patients with fever or respiratory } \\
\text { symptoms from Wuhan or the surrounding areas, } \\
\text { or from communities with reported COVID-19 } \\
\text { cases, within } 14 \text { days before illness onset; } \\
\text { (4) Had clustering occurrence ( } \geq 2 \text { cases with } \\
\text { fever and/or respiratory symptoms in a small } \\
\text { area such as a family, an office, a school class, } \\
\text { etc., within } 2 \text { weeks). } \\
\text { 2. Clinical manifestations: } \\
\text { (1) Fever and/or respiratory symptoms; }\end{array}$ & $\begin{array}{l}\text { 1. Respiratory or blood specimens } \\
\text { tested positive for the nucleic acid of } \\
\text { SARS-CoV-2 by the real-time } \\
\text { fluorescent RT-PCR; } \\
\text { 2. Viruses isolated from respiratory or } \\
\text { blood specimens showing high } \\
\text { homology with a known SARS-CoV-2 } \\
\text { by whole genome sequencing; } \\
\text { 3. Serum tested positive for SARS- } \\
\text { CoV-2 specific IgM and IgG } \\
\text { antibodies; the serum SARS-CoV-2- } \\
\text { specific IgG antibody test changed } \\
\text { from negative (undetectable) to } \\
\text { positive (detectable), or the IgG } \\
\text { antibody level is } 4 \text { times higher in the } \\
\text { convalescent serum than in the serum } \\
\text { collected at the acute phase of the } \\
\text { infection. }\end{array}$ \\
\hline
\end{tabular}




\begin{tabular}{|c|c|c|c|c|}
\hline & $\begin{array}{l}\text { (2) Pneumonia indicated by chest radiograph; } \\
\text { (3) Low or normal white blood cell count, or low } \\
\text { lymphocyte count during early onset; }\end{array}$ & & & \\
\hline $\begin{array}{c}\text { City of } \\
\text { Toronto(20) } \\
\text { (April2, 2020) }\end{array}$ & - & $\begin{array}{l}\text { A. A person with fever (over } 38 \\
\text { degrees Celsius) and/or onset of (or } \\
\text { exacerbation of chronic) cough } \\
\text { AND any of the following within } 14 \\
\text { days prior to onset of illness: } \\
\text { - Travel to an impacted area or } \\
\text { - Close contact with a confirmed } \\
\text { or probable case of COVID-19 } \\
\text { or } \\
\text { Close contact with a person } \\
\text { with acute respiratory illness } \\
\text { who has been to an impacted } \\
\text { area AND } \\
\text { In whom laboratory diagnosis of } \\
\text { COVID-19 is not available, }\end{array}$ & $\begin{array}{l}\text { A person with laboratory confirmation } \\
\text { of COVID-19 infection using a } \\
\text { validated assay, consisting of positive } \\
\text { nucleic acid amplification test }\end{array}$ & - \\
\hline
\end{tabular}




\begin{tabular}{|c|c|c|c|c|}
\hline & & $\begin{array}{l}\text { inconclusive, or negative (if } \\
\text { specimen quality or timing is } \\
\text { suspect) }\end{array}$ & & \\
\hline Pakistan & $\begin{array}{l}\text { A. A patient with acute respiratory illness (fever } \\
\text { and at least one sign/symptom of respiratory } \\
\text { disease, e.g., cough, shortness of breath), AND a } \\
\text { history of travel to or residence in a location } \\
\text { reporting community transmission of COVID-19 } \\
\text { disease during the } 14 \text { days prior to symptom } \\
\text { onset. } \\
\text { OR } \\
\text { B. A patient with any acute respiratory illness } \\
\text { AND having been in contact with a confirmed or } \\
\text { probable COVID-19 case (see definition of } \\
\text { contact) in the last } 14 \text { days prior to symptom } \\
\text { onset; } \\
\text { OR } \\
\text { C. A patient with severe acute respiratory illness } \\
\text { (fever and at least one sign/symptom of }\end{array}$ & $\begin{array}{l}\text { A. A suspect case for whom testing } \\
\text { for the COVID-19 virus is } \\
\text { inconclusive. } \\
\text { - Inconclusive being the result of } \\
\text { the test reported by the laboratory } \\
\text { OR } \\
\text { B. A suspect case for whom testing } \\
\text { could not be performed for any } \\
\text { reason }\end{array}$ & $\begin{array}{l}\text { A person with laboratory confirmation } \\
\text { of COVID-19 infection, irrespective of } \\
\text { clinical signs and symptoms. }\end{array}$ & \\
\hline
\end{tabular}




\begin{tabular}{|c|c|c|c|c|}
\hline & $\begin{array}{l}\text { respiratory disease, e.g. cough, shortness of } \\
\text { breath; AND requiring hospitalization) AND in } \\
\text { the absence of an alternative diagnosis that fully } \\
\text { explains the clinical presentation. }\end{array}$ & & & \\
\hline $\begin{array}{c}\text { New Zealand's } \\
\text { Ministry of } \\
\text { Health }\end{array}$ & $\begin{array}{l}\text { A suspect case satisfies the following clinical } \\
\text { criteria: } \\
\text { Fever ( } \geq 38 \mathrm{oC}) \text { AND/OR any acute respiratory } \\
\text { infection with at least one of the following } \\
\text { symptoms: cough, sore throat or shortness of } \\
\text { breath } \\
\text { Symptomatic close contacts of suspect or } \\
\text { probable cases should be considered suspect } \\
\text { cases }\end{array}$ & $\begin{array}{l}\text { A close contact of a confirmed case } \\
\text { (epi-link) OR a case that meets the } \\
\text { clinical criteria where other known } \\
\text { etiologies that fully explain the } \\
\text { clinical presentation have been } \\
\text { excluded and either has laboratory } \\
\text { suggestive evidence or for whom } \\
\text { testing for SARS-CoV-2 is } \\
\text { inconclusive }\end{array}$ & $\begin{array}{l}\text { A case that has laboratory definitive } \\
\text { evidence. } \\
\text { Laboratory definitive evidence } \\
\text { requires at least one of the following: } \\
\text { - detection of SARS-CoV-2 from a } \\
\text { clinical specimen using a validated } \\
\text { NAAT (PCR) } \\
\text { - detection of coronavirus from a } \\
\text { clinical specimen using pan- } \\
\text { coronavirus NAAT (PCR) and } \\
\text { confirmation as SARS-CoV-2 by } \\
\text { sequencing } \\
\text { - Significant rise in IgG antibody level } \\
\text { to SARS-CoV-2 between paired sera }\end{array}$ & $\begin{array}{l}\text { Under investigation } \\
\text { case: } \\
\text { A suspect or probable } \\
\text { case that meets the } \\
\text { prioritisation criteria } \\
\text { for testing above, but } \\
\text { information is not yet } \\
\text { available to classify it } \\
\text { as confirmed or not a } \\
\text { case } \\
\text { Not a case } \\
\text { An 'under } \\
\text { investigation' case who } \\
\text { has a negative test. }\end{array}$ \\
\hline
\end{tabular}




\begin{tabular}{|c|c|c|c|}
\hline & $\begin{array}{l}\text { contact, in the last } 14 \text { days, with someone else } \\
\text { who has recently travelled overseas } \\
\text { - hospital in patients who meet the clinical } \\
\text { criteria } \\
\text { - health care workers meeting the clinical criteria } \\
\text { - other essential workers meeting the clinical } \\
\text { criteria if they have had close or casual contact } \\
\text { with a probable or confirmed COVID-19 case } \\
\text { - people meeting the clinical criteria who reside } \\
\text { in (or are being admitted into) a vulnerable } \\
\text { communal environment including aged } \\
\text { residential care, or large extended families in } \\
\text { confined household/ living conditions } \\
\text { - people meeting the clinical criteria who may } \\
\text { expose a large number of contacts to infection } \\
\text { (including barracks, hostels, halls of residence, } \\
\text { shelters etc.) In addition, testing may be required }\end{array}$ & $\begin{array}{l}\text { (when serological testing becomes } \\
\text { available). }\end{array}$ & $\begin{array}{l}\text { Not tested } \\
\text { The key principle is to } \\
\text { reduce transmission } \\
\text { from person to person. } \\
\text { That means reducing } \\
\text { the contact that } \\
\text { people who may have } \\
\text { the virus have with } \\
\text { others while they are } \\
\text { infectious }\end{array}$ \\
\hline
\end{tabular}




\begin{tabular}{|c|c|c|c|}
\hline & $\begin{array}{l}\text { - on advice from the local Medical Officer of } \\
\text { Health, when an outbreak or cluster is suspected, } \\
\text { or being investigated }\end{array}$ & & \\
\hline $\begin{array}{l}\text { Australian } \\
\text { government }\end{array}$ & $\begin{array}{l}\text { If the patient satisfies epidemiological and } \\
\text { clinical criteria, they are classified as a suspect } \\
\text { case. } \\
\text { Epidemiological criteria } \\
\text { - Travel to (including transit through) a } \\
\text { country considered to pose a risk of } \\
\text { transmission in the } 14 \text { days before the onset } \\
\text { of illness. } \\
\text { OR } \\
\text { Close or casual contact in } 14 \text { days before } \\
\text { illness onset with a confirmed case of } \\
\text { COVID-19. } \\
\text { Clinical criteria } \\
\text { Fever OR acute respiratory infection (e.g. } \\
\text { shortness of breath or cough) with or } \\
\text { without fever. }\end{array}$ & $\begin{array}{l}\text { A person who tests positive to a specific } \\
\text { SARS-CoV-2 PCR test or has the virus } \\
\text { identified by electron microscopy or } \\
\text { viral culture, at a reference laboratory }\end{array}$ & \\
\hline
\end{tabular}




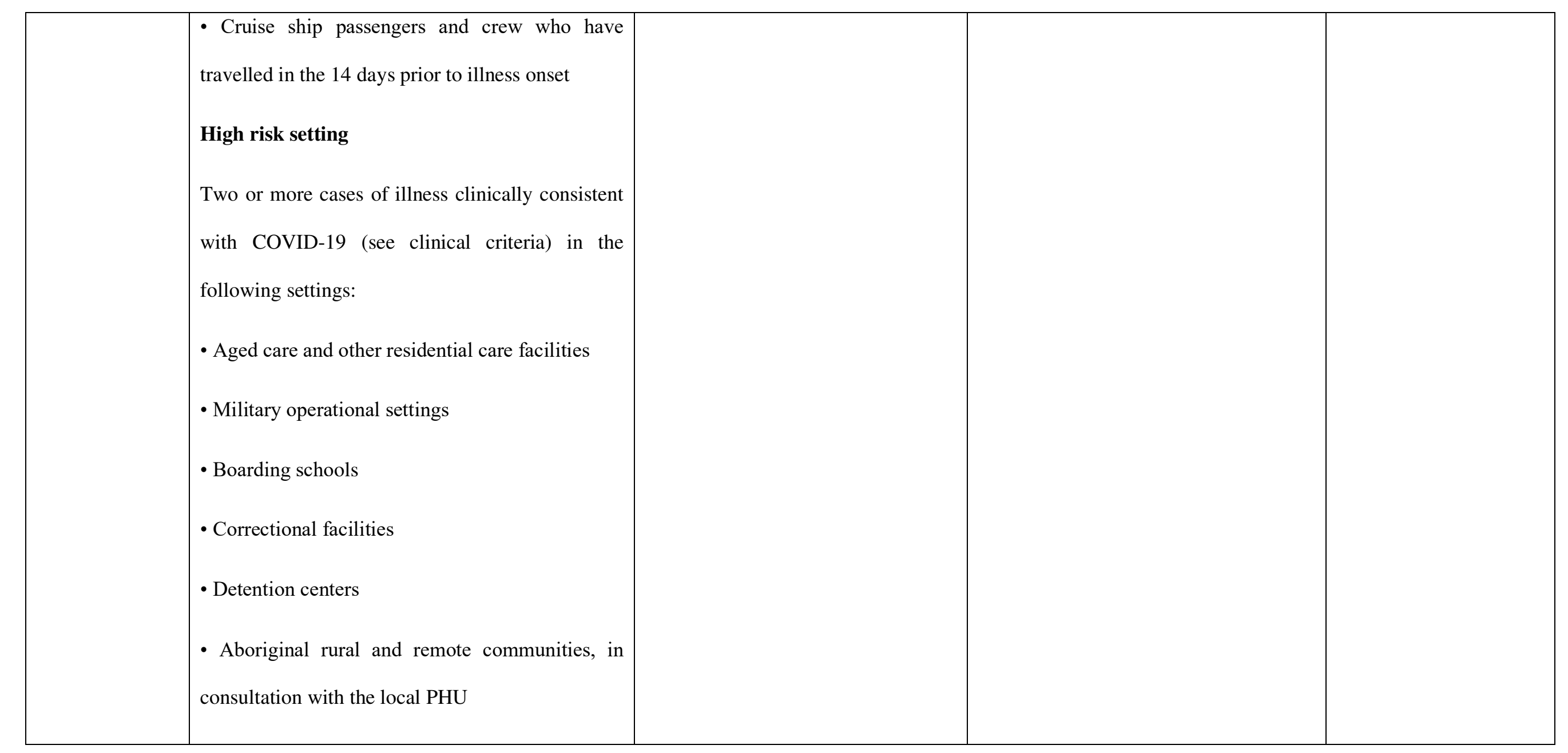




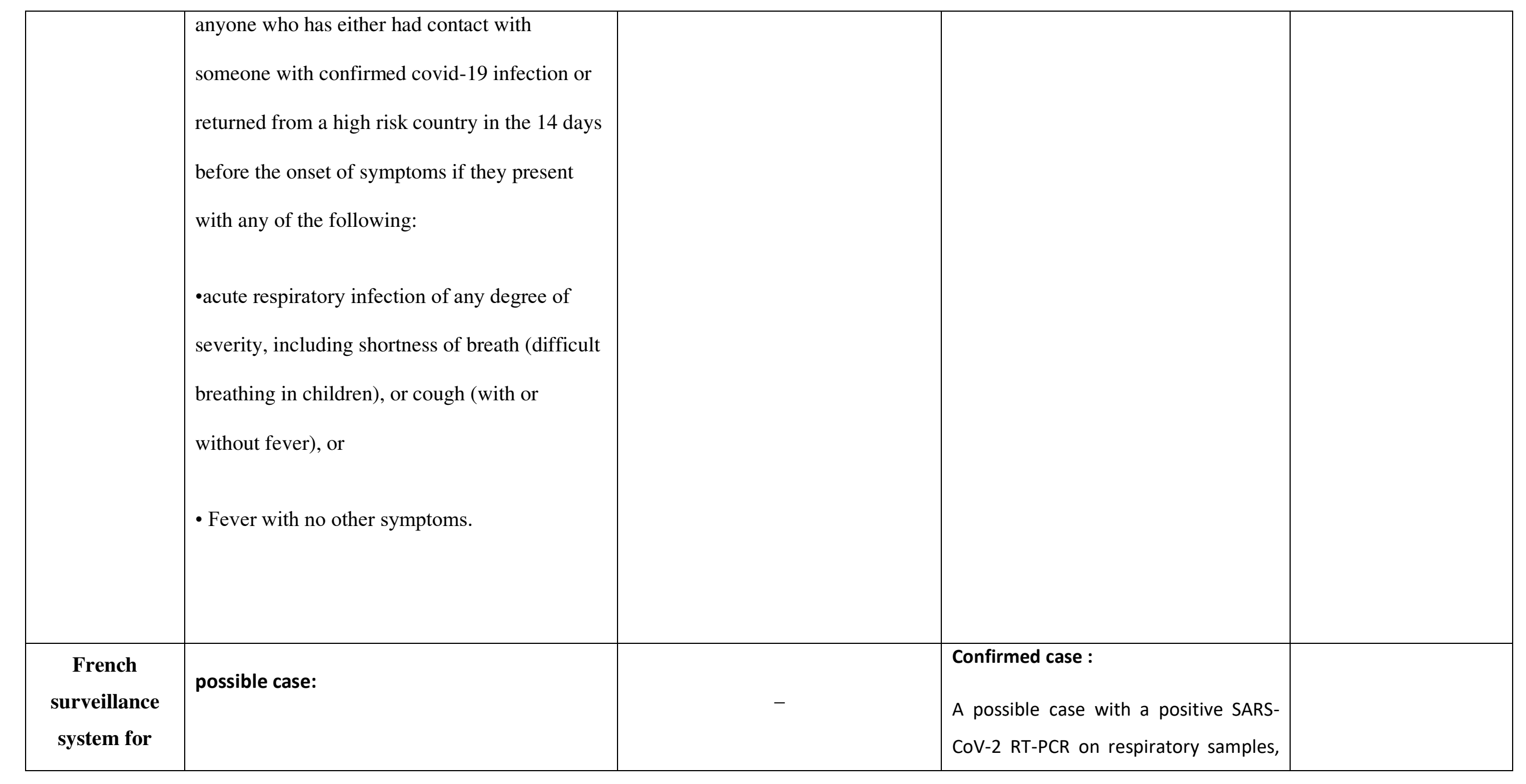




\begin{tabular}{|c|c|c|c|}
\hline $\begin{array}{c}\text { novel } \\
\text { coronavirus } \\
\text { (10 January) }\end{array}$ & $\begin{array}{l}\text { patient with a severe acute lower respiratory } \\
\text { infection requiring admission to hospital and } \\
\text { with a history of travel to or residence in Wuhan, } \\
\text { China in the } 14 \text { days before symptom onset, } \\
\text { or } \\
\text { A patient with an acute respiratory illness } \\
\text { whatever the severity and with a history of at- } \\
\text { risk exposure, mainly to a confirmed case. }\end{array}$ & $\begin{array}{l}\text { performed by an accredited laboratory. } \\
\text { Testing relied on the real-time RT-PCR } \\
\text { procedure developed by the Charité [4] } \\
\text { as well as on the use of real-time RT-PCR } \\
\text { specific for the RdRp gene (four targets) } \\
\text { designed at Institute Pasteur (RdRp-IP). }\end{array}$ & \\
\hline $\begin{array}{c}\text { European } \\
\text { Centre for } \\
\text { Disease } \\
\text { Prevention } \\
\text { and Control }\end{array}$ & \multicolumn{3}{|c|}{ Based on WHO case definition } \\
\hline
\end{tabular}


(2 March

2020) 
Table 2: Epidemiological characteristics of COVID-19 based on Gregg classification

\begin{tabular}{|c|c|c|c|c|c|}
\hline Study & $\begin{array}{l}\text { Type of } \\
\text { review }\end{array}$ & Clinical feature & Person & Place & Time \\
\hline (21) & scoping review & $\begin{array}{l}\text { Most common symptoms: } \\
\text { - } \text { Fever } \\
\text { - cough } \\
\text { - } \text { myalgia or fatigue } \\
\text { - } \text { pneumonia, } \\
\text { - complicated dyspnea } \\
\text { Less common symptoms } \\
\text { - headache } \\
\text { - diarrhea } \\
\text { - hemoptysis } \\
\text { - runny nose } \\
\text { - phlegm producing cough } \\
\text { Diagnostic tests } \\
\text { - real-time fluorescence (RT- } \\
\text { PCR) to detect the positive } \\
\text { nucleic acid of SARS-CoV-2 in } \\
\text { sputum }\end{array}$ & $\begin{array}{l}\text { Age } \\
\text { - } \quad \text { Age distribution of adult } \\
\text { patients } 25-89 \\
\text { - Most adult patients } 35-55 \\
\text { - Median age of death was } 75 \text { ( a } \\
\text { range 48-89) } \\
\text { Asymptomatic persons } \\
\text { there were fewer identified cases } \\
\text { among children and infants } \\
\text { Gender } \\
\text { - More cases were males(59\% } \\
\text { males, } 68 \% \text { males ) } \\
\text { Susceptible populations } \\
\text { People with: } \\
\text { - Elderly } \\
\text { - chronic co-morbidities } \\
\text { - } \quad \text { poor immune function }\end{array}$ & $\begin{array}{l}\text { - local seafood market } \\
\text { ("wet market") } \\
\text { - Wuhan residents or } \\
\text { people who visited } \\
\text { Wuhan } \\
\text { - human-to-human } \\
\text { transmission via } \\
\text { close contact }\end{array}$ & $\begin{array}{l}\text { incubation period from } \\
\text { exposure to symptoms } \\
\text { - From 2-14 days }\end{array}$ \\
\hline
\end{tabular}




\begin{tabular}{|c|c|c|c|c|c|}
\hline & & $\begin{array}{l}\text { - } \text { throat swabs } \\
\text { - } \text { secretions of the lower } \\
\text { respiratory tract samples }\end{array}$ & $\begin{array}{l}\text { - } \text { long-term use of } \\
\text { immunosuppressive agents } \\
\text { - } \quad \text { Surgery history before } \\
\text { admission }\end{array}$ & & \\
\hline (21) & $\begin{array}{c}\text { Narrative } \\
\text { review }\end{array}$ & $\begin{array}{l}\text { Most common symptoms } \\
\text { - fever } \\
\text { - fatigue } \\
\text { - dry cough } \\
\text { - myalgia } \\
\text { - dyspnea } \\
\text { - leucopenia and lymphopenia } \\
\text { Less common symptoms } \\
\text { - } \text { sputum production, } \\
\text { - headache, } \\
\text { - hemoptysis and diarrhea } \\
\text { - pleuritic chest pain } \\
\text { Diagnostic tests } \\
\text { RT-PCR to detect causative viruses } \\
\text { from respiratory secretions. }\end{array}$ & $\begin{array}{l}\text { Age } \\
\text { - Most case patients were } 30-79 \\
\text { years of age } 32(21) \\
\text { - The median age is ranging } \\
\text { from } 49 \text { to } 59 \text { years }(21) \\
\text { Asymptomatic persons } \\
\text { There were few cases in children } \\
\text { below } 15 \text { years of age } \\
\text { Gender } \\
\text { More than half the patients were } \\
\text { male(21) } \\
\text { Susceptible populations }\end{array}$ & $\begin{array}{l}\text { major route of } \\
\text { transmission of COVID- } \\
19 \text { is droplet and close } \\
\text { contact }\end{array}$ & $\begin{array}{l}\text { incubation period from } \\
\text { exposure to symptoms } \\
\text { - 14-day medical } \\
\text { observation period or } \\
\text { quarantine for } \\
\text { exposed and close } \\
\text { contact persons } \\
\text { - duration period from } \\
\text { illness onset to } \\
\text { dyspnea was } 8.0 \text { days } \\
\text { - and to mechanical } \\
\text { ventilation was } 10.5 \\
\text { day }\end{array}$ \\
\hline
\end{tabular}




\begin{tabular}{|c|c|c|c|c|c|}
\hline & & & $\begin{array}{l}\text { Nearly half the cases had one or } \\
\text { more coexisting medical } \\
\text { conditions, such as hypertension, } \\
\text { diabetes and cardiovascular disease }\end{array}$ & & \\
\hline (22) & $\begin{array}{l}\text { Systematic } \\
\text { review and } \\
\text { meta-analysis }\end{array}$ & $\begin{array}{l}\text { Most common symptoms } \\
\text { - } \quad \text { Fever ( } 88.7 \%) \\
\text { - } \quad \text { Cough (57.6\%) } \\
\text { - } \quad \text { Dyspnea (45.6\%) } \\
\text { - } \quad \text { Myalgia (31.0\%) } \\
\text { laboratory findings: } \\
\text { - } \quad \text { Decreased albumin (75.8\%) } \\
\text { - High C-reactive protein (58.3\%) } \\
\text { - High lactate dehydrogenase (LDH) } \\
\text { (57.0\%) } \\
\text { - } \quad \text { Lymphopenia (43.1\%) } \\
\text { - High erythrocyte sedimentation } \\
\text { rate (ESR) (41.8\%) } \\
\text { Pneumonia compromise was } \\
\text { predominantly bilateral ( } 72.9 \%) \\
\text { with image findings ground- } \\
\text { glass opacity in } 68.5 \% \text { in those } \\
\text { with X ray results. }\end{array}$ & $\begin{array}{l}\text { Age } \\
\text { In case reports the mean age was } \\
47.9 \text { y-old } \\
\text { Asymptomatic persons } \\
\text { Gender } \\
\text { being male } 55.9 \%(22)\end{array}$ & - & - \\
\hline
\end{tabular}




\begin{tabular}{|c|c|c|c|c|c|}
\hline & & & $\begin{array}{l}\text { Susceptible populations } \\
\text { The most prevalent comorbidity: } \\
\text { - Hypertension }(17 \%) \\
\text { - Diabetes }(8 \%) \\
\text { - Cardiovascular diseases }(5 \%) \\
\text { - Respiratory system disease } \\
(2 \%)\end{array}$ & & \\
\hline (23) & $\begin{array}{c}\text { Systematic } \\
\text { review }\end{array}$ & $\begin{array}{l}\text { Most common symptoms } \\
\text { - } \quad \text { Fever }(86.0 \%), \\
\text { - } \quad \text { Cough }(63.9 \%) \\
\text { - } \quad \text { Malaise/Fatigue/Confusion } \\
\quad(34.7 \%) \\
\text { - } \quad \text { Sputum production }(28.9 \%) \\
\text { - } \quad \text { Shortness of breath }(19.7 \%) \\
\text { - } \quad \text { Myalgia (18.8\%) } \\
\\
\text { Less common symptoms } \\
\text { - } \quad \text { Diarrhea (5.7\%) } \\
\text { - } \quad \text { Nausea/vomiting }(6.1 \%)\end{array}$ & $\begin{array}{l}3.9 \% \text { of cases were health workers } \\
\text { Gender } \\
51.7 \% \text { were male (male: } \\
\text { female=1.07:1). }\end{array}$ & 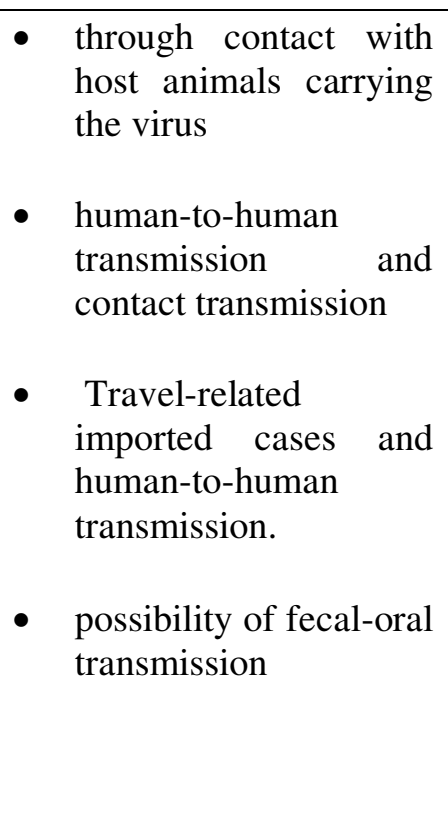 & - \\
\hline
\end{tabular}




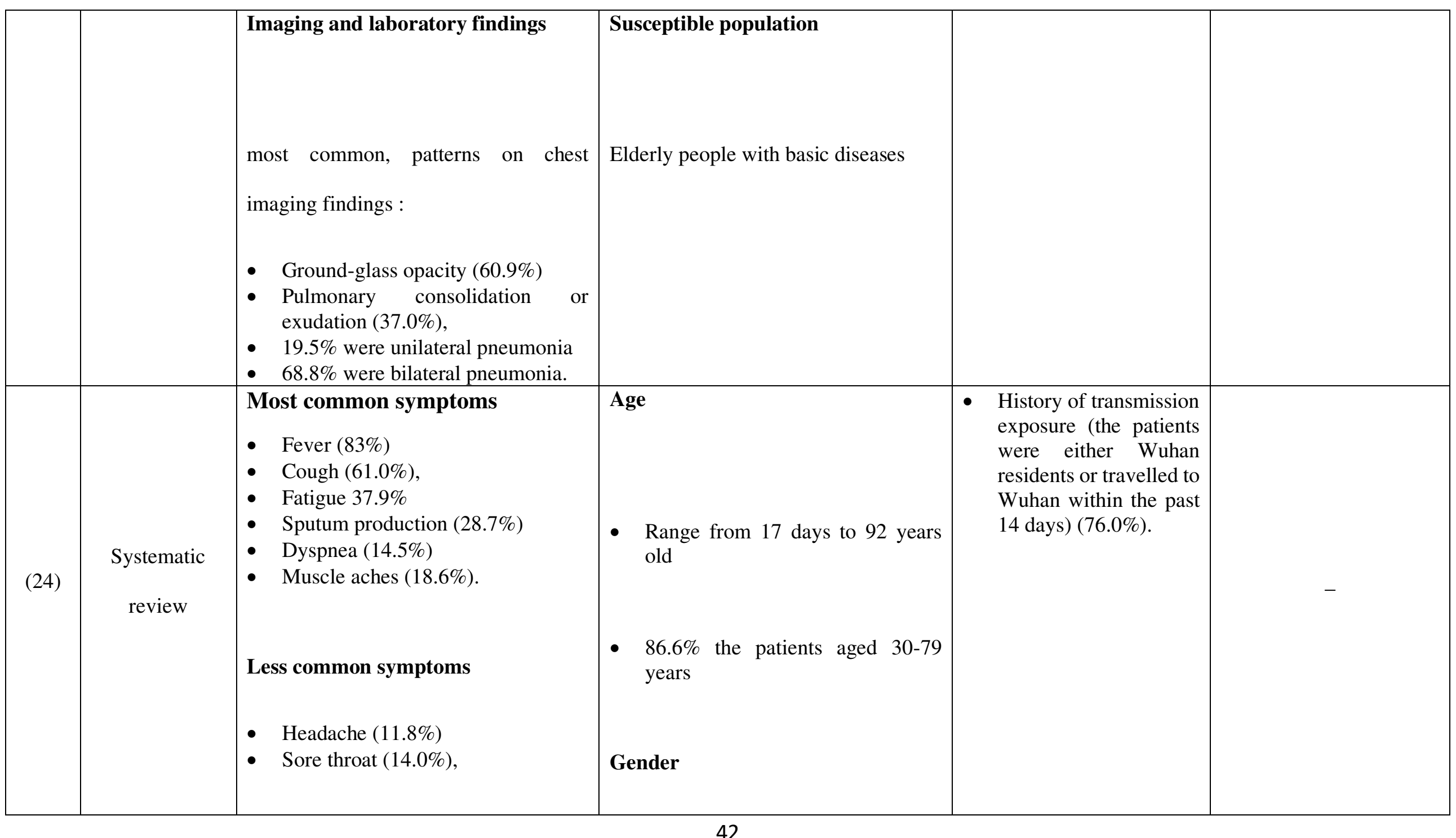




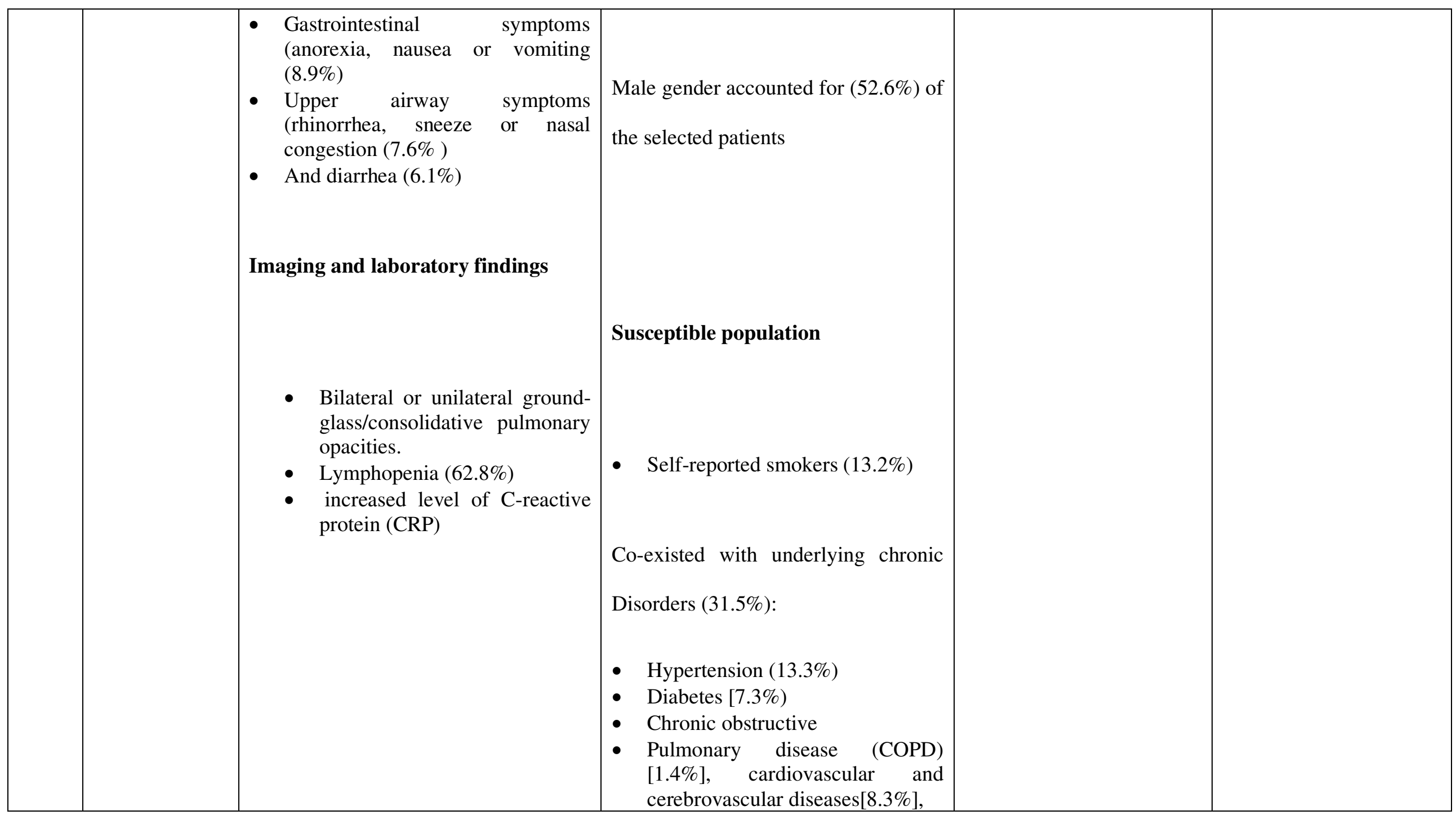




\begin{tabular}{|c|c|c|c|c|c|}
\hline & & & $\begin{array}{l}\text { - } \quad \text { Malignancy [1.5\%], } \\
\text { - } \quad \text { Chronic liver disease [2.1\%] } \\
\text { - Chronic kidney disease [0.7\%] }\end{array}$ & & \\
\hline (25) & $\begin{array}{l}\text { Narrative } \\
\text { review }\end{array}$ & $\begin{array}{l}\text { Most common symptoms } \\
\text { - Fever ( } 90 \% \text { or more), } \\
\text { - Cough (around } 75 \%) \text {, } \\
\text { - Dyspnea (up to } 50 \% \text { ) } \\
\text { - Bilateral lung ground glass } \\
\text { opacity on computed } \\
\text { tomography imaging } \\
\text { Less common symptoms } \\
\text { - gastrointestinal symptoms } \\
\text { Diagnostic tests } \\
\text { - Real-time reverse transcription } \\
\text { polymerase chain reaction (RT- } \\
\text { PCR) and next-generation } \\
\text { sequencing } \\
\text { Fomites are suspected as the main } \\
\text { source of infectious particles, } \\
\text { though some uncertainty remains. } \\
\text { - SARS-CoV-2 RNA was detected in } \\
\text { the stool specimen in a person who } \\
\text { had symptoms while the serum } \\
\text { specimen tested negative. }\end{array}$ & $\begin{array}{l}\text { Susceptible populations } \\
\text { older males with comorbidities as a } \\
\text { result of weaker immune function }\end{array}$ & $\begin{array}{l}\text { - Potential for fecal-oral } \\
\text { transmission. } \\
\text { - person-to-person } \\
\text { transmission } \\
\text { - it appears that } \\
\text { asymptomatic persons } \\
\text { are also potential } \\
\text { sources of 2019-nCoV } \\
\text { infection }\end{array}$ & \\
\hline
\end{tabular}




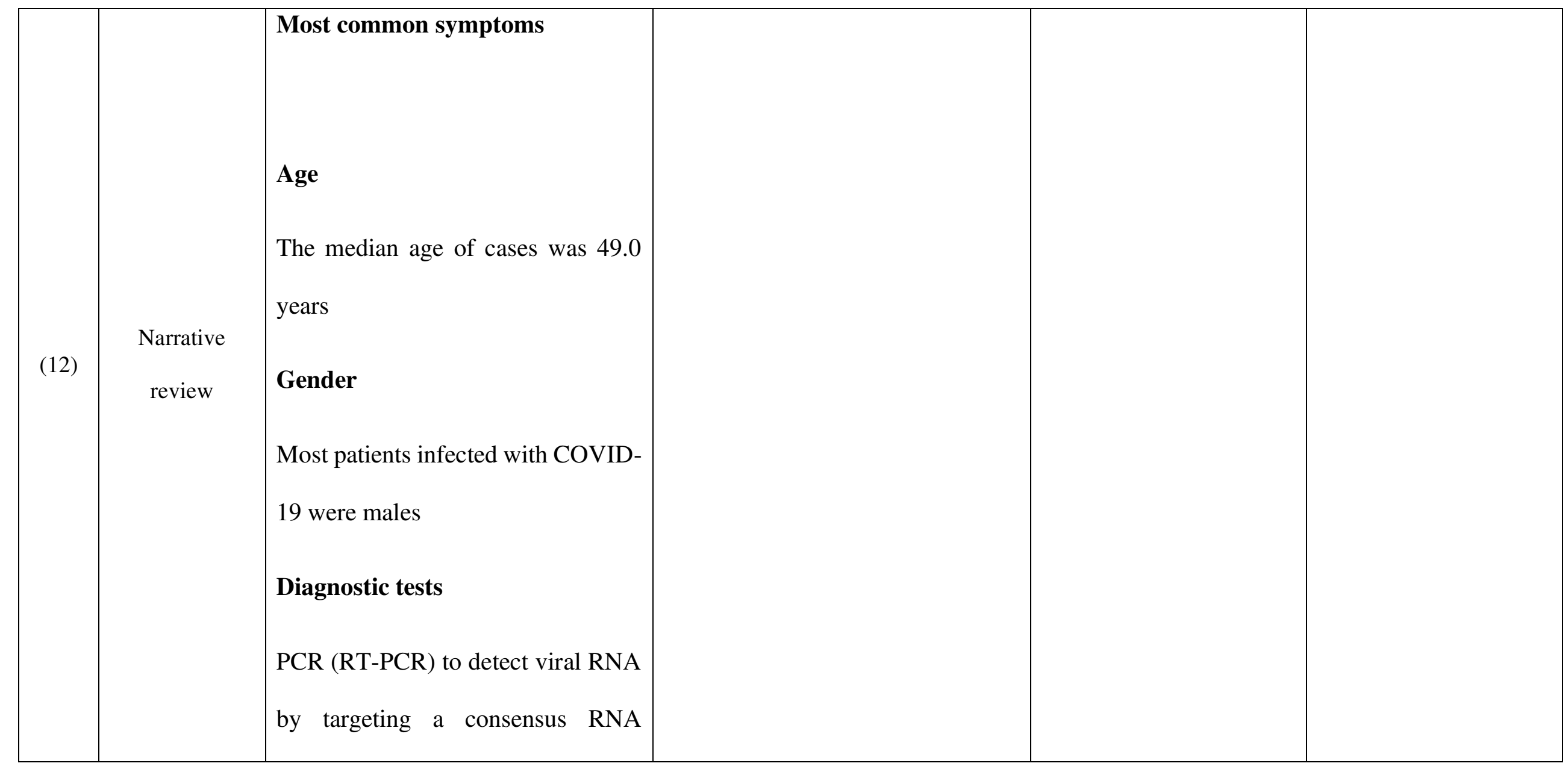




\begin{tabular}{|c|c|c|c|c|}
\hline & & $\begin{array}{l}\text { dependent RNA polymerase region } \\
\text { of pan b-CoV }\end{array}$ & & \\
\hline (26) & $\begin{array}{c}\text { Narrative } \\
\text { review }\end{array}$ & $\begin{array}{l}\text { Most common symptoms } \\
\text { - } \text { fever } \\
\text { - } \text { cough } \\
\text { - fatigue } \\
\text { Less common symptoms } \\
\text { - } \text { sputum production, } \\
\text { - headache, } \\
\text { - hemoptysis } \\
\text { - diarrhea } \\
\text { - dyspnea } \\
\text { - lymphopenia } \\
\text { - gastrointestinal } \\
\text { - } \text { symptoms like diarrhea } \\
\text { - chest CT scan presented as } \\
\text { pneumonia, however, there were } \\
\text { abnormal features such as } \\
\text { RNAaemia, acute respiratory } \\
\text { distress syndrome } \\
\text { - multiple peripheral ground-glass } \\
\text { opacities were observed in sub } \\
\text { pleural regions of both lungs }\end{array}$ & $\begin{array}{l}\text { - Person-to-person } \\
\text { transmission occurs } \\
\text { primarily via direct } \\
\text { contact or through } \\
\text { droplets spread by } \\
\text { coughing or sneezing } \\
\text { from an infected } \\
\text { individual }\end{array}$ & $\begin{array}{l}\text { The symptoms of } \\
\text { COVID-19 infection } \\
\text { appear after an } \\
\text { incubation } \\
\text { period of approximately } \\
5.2 \text { days } \\
\text { The period from the onset } \\
\text { of COVID-19 symptoms } \\
\text { to death ranged from } 6 \text { to } \\
41 \text { days with a median } \\
\text { of } 14 \text { days }\end{array}$ \\
\hline
\end{tabular}




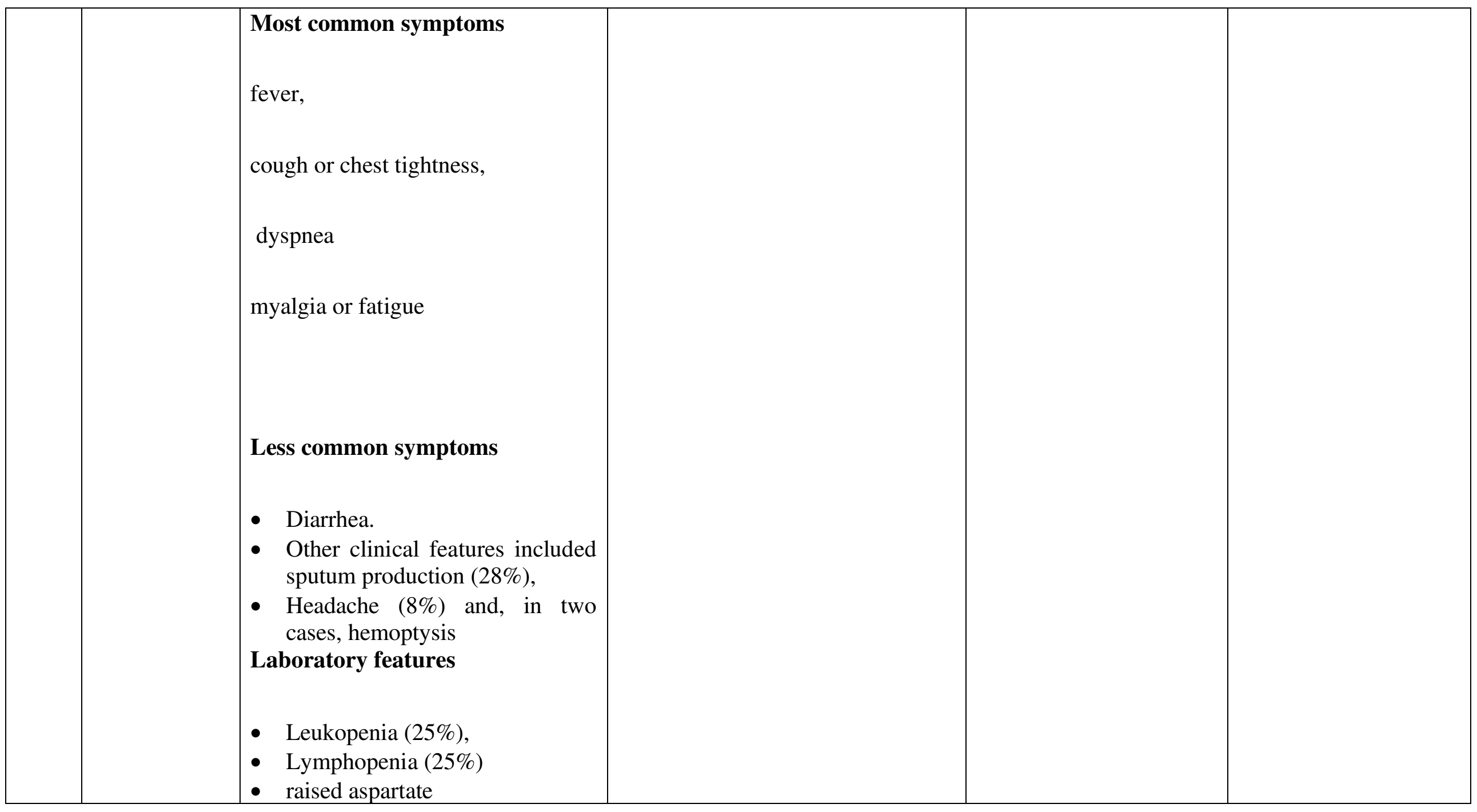




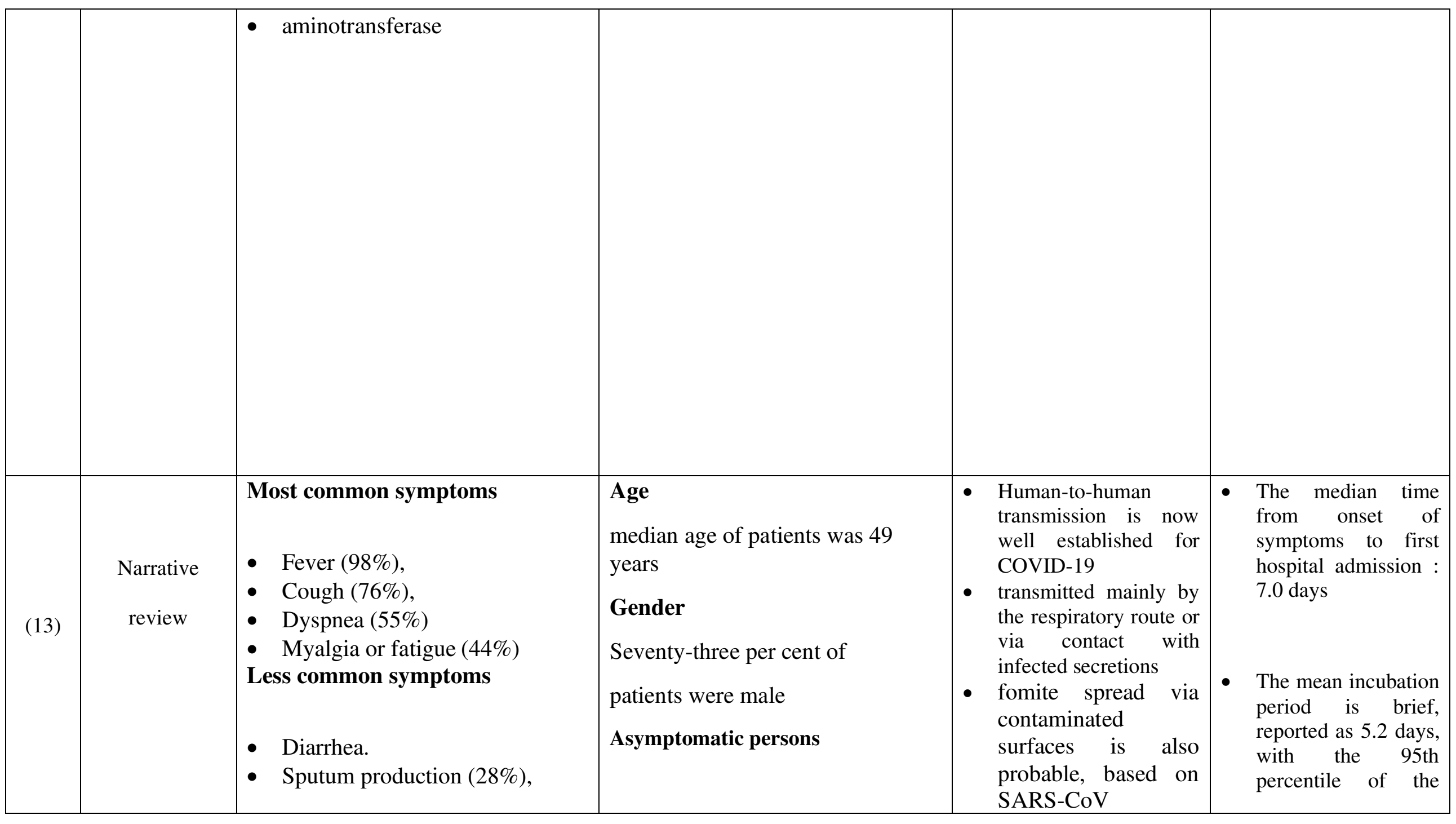




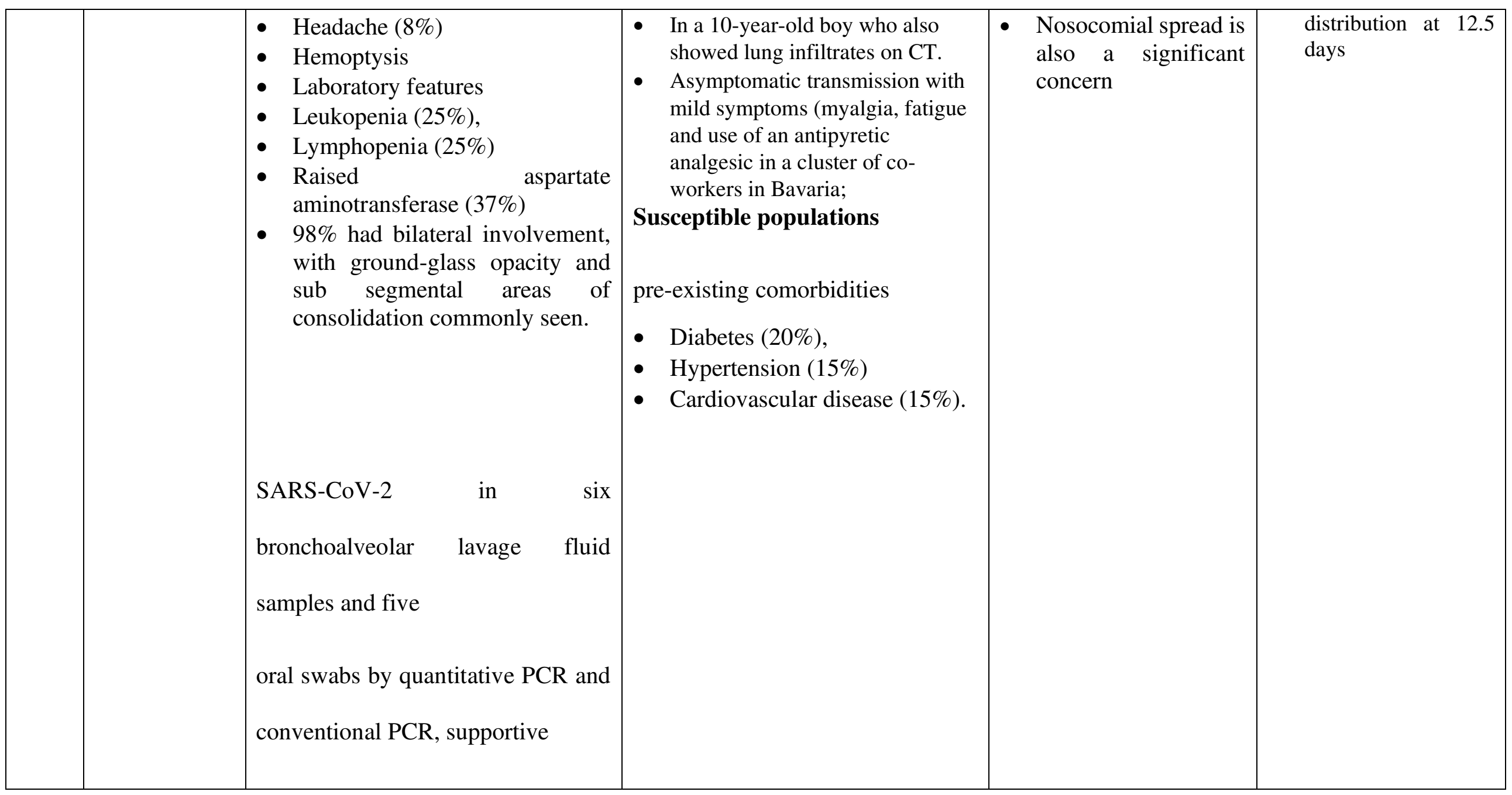




\begin{tabular}{|c|c|c|c|c|c|}
\hline & & $\begin{array}{l}\text { of a respiratory transmission route. } 3 \\
\text { Virus has also been detected } \\
\text { in patient stool samples. }\end{array}$ & & & \\
\hline (16) & $\begin{array}{c}\text { Narrative } \\
\text { review }\end{array}$ & $\begin{array}{l}\text { Classification in } 4 \text { levels based on } \\
\text { the severity of symptoms: } \\
\text { Mild: } \\
\text { - mild symptoms without } \\
\text { radiographic features } \\
\text { Moderate: } \\
\text { - fever, } \\
\text { - respiratory symptoms } \\
\text { - radiographic features }\end{array}$ & $\begin{array}{l}\text { Age: } \\
\text { - Patients aged from } 30 \text { to } 79 \\
\text { accounted for } 86.6 \% \text { of all } \\
\text { cases } \\
\text { - The median age of the patients } \\
\text { was } 47 \text { years30 } \\
\text { Susceptible populations } \\
\text { Age and comorbidity may be } \\
\text { risk factors. }\end{array}$ & 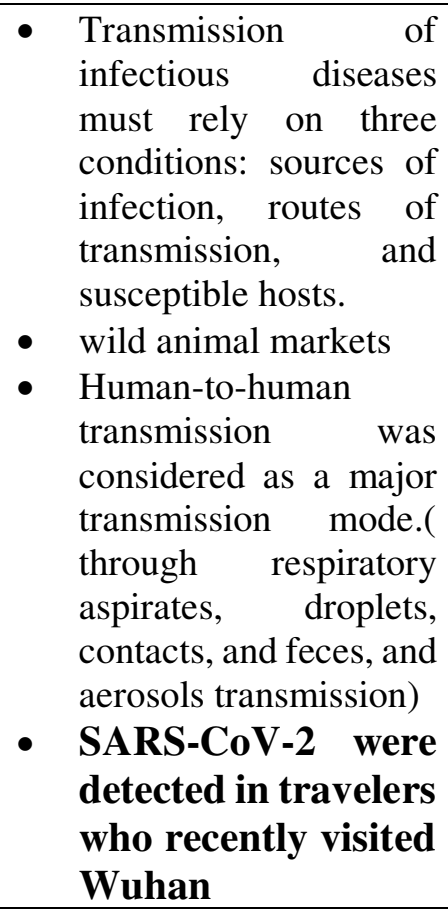 & $\begin{array}{l}\text { The median time from } \\
\text { first symptom to dyspnea } \\
\text { was } 5.0 \text { days, to hospital } \\
\text { admission was } 7.0 \text { days, } \\
\text { and to ARDS was } 8.0 \\
\text { days } 23\end{array}$ \\
\hline
\end{tabular}




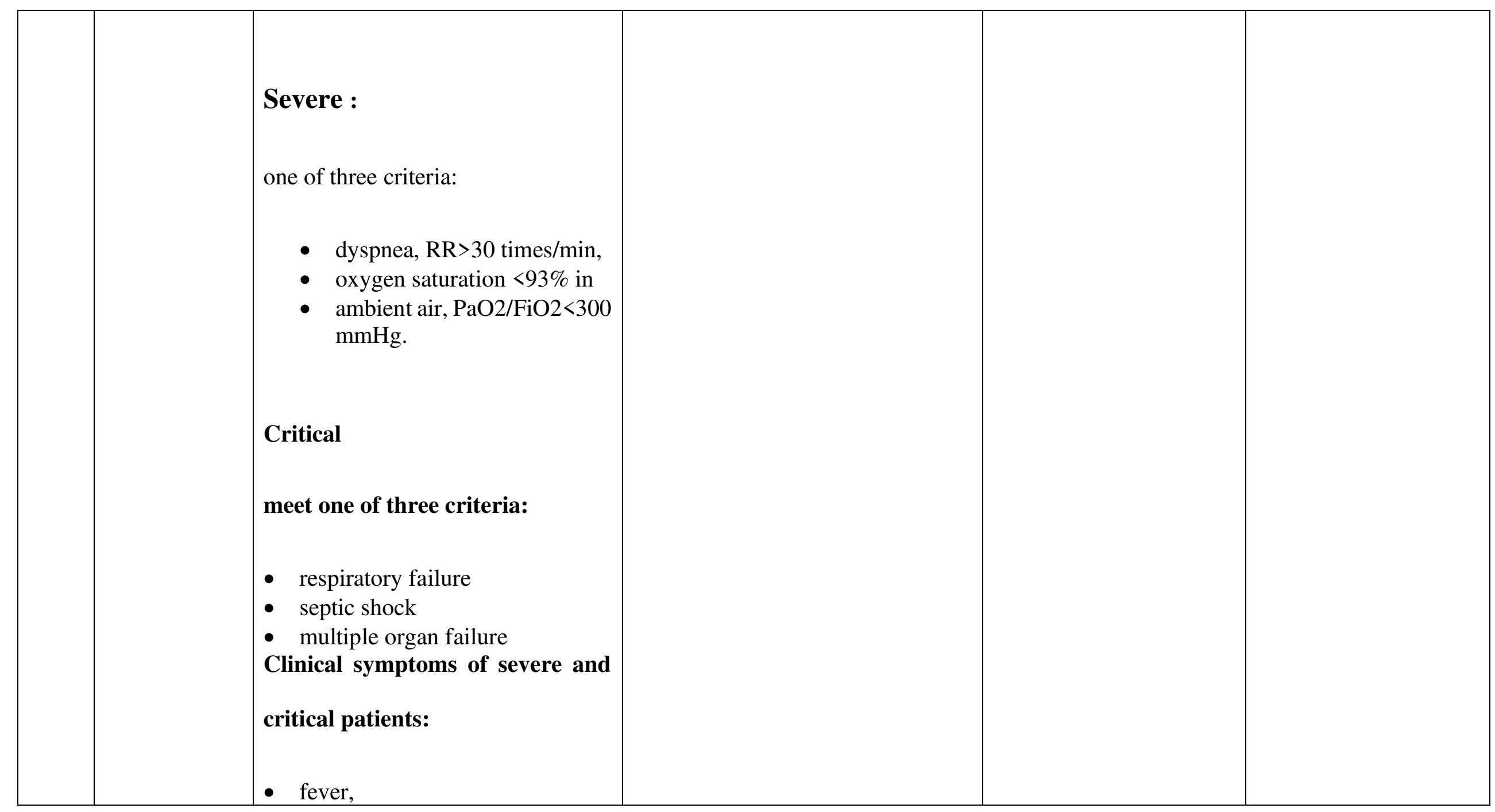




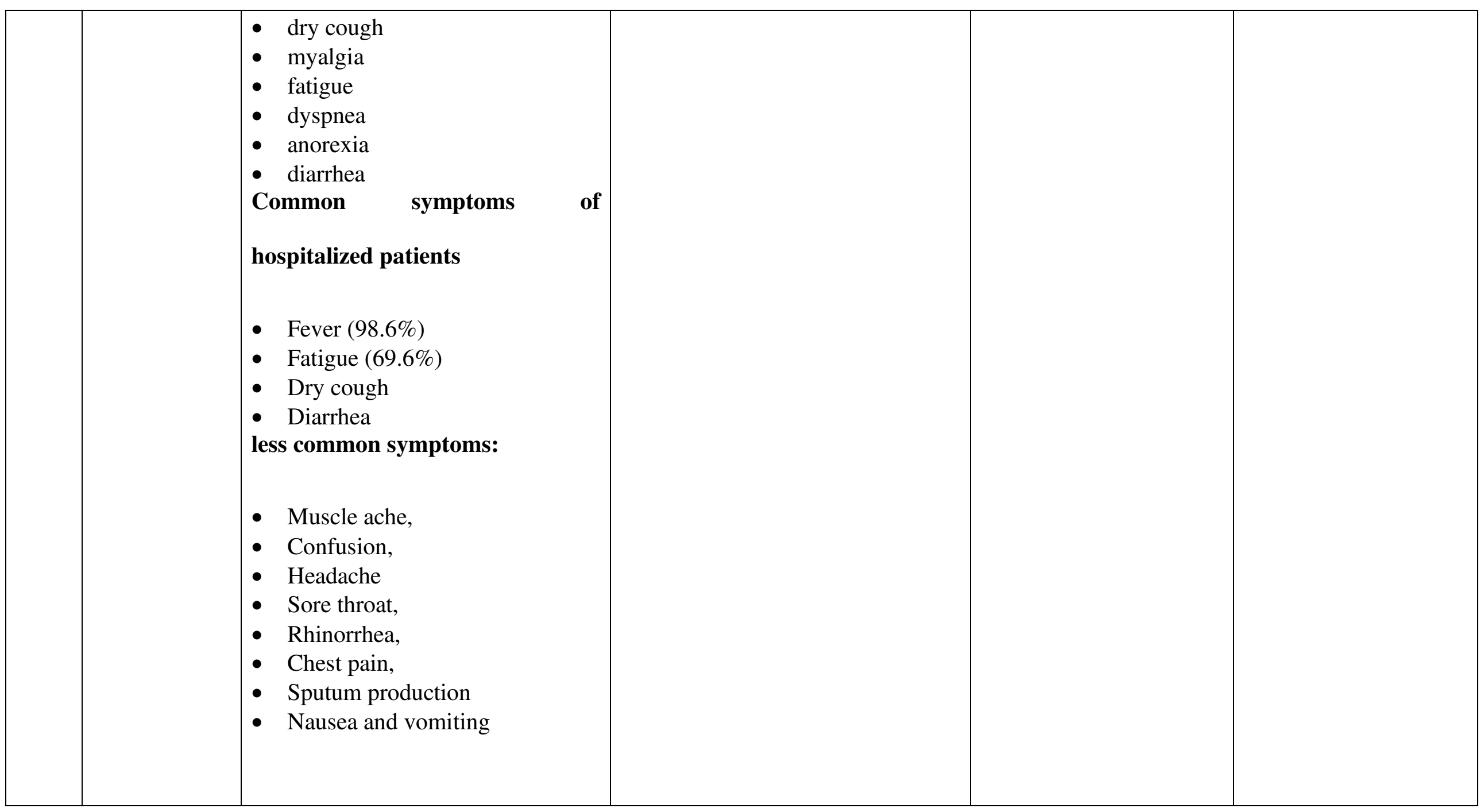




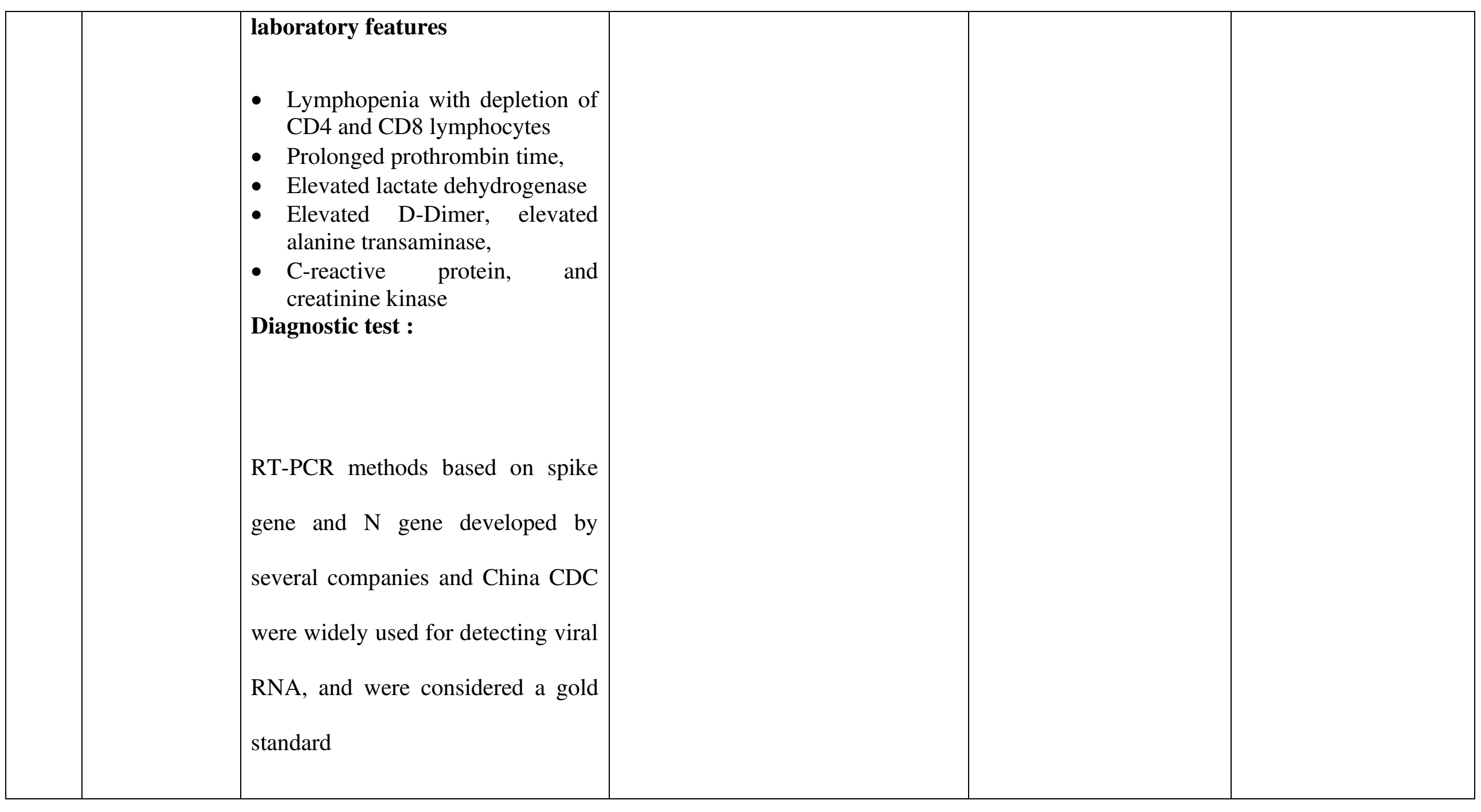


Figures

\begin{tabular}{|c|c|c|c|c|c|c|c|c|c|c|c|c|c|c|c|}
\hline & Sn & Sp & LR+ & LR- & & CT & + & + & - & - & + & - & NP & NP & NP \\
\hline CT & 66 & 80 & 3.3 & 0.41 & & & & & & & & & & & \\
\hline RT-PCR & 0.6 & 99.6 & 150 & 0.4 & & RI-PCR & + & - & + & - & NP & NP & + & - & NP \\
\hline & & & & & & & $\downarrow$ & $\downarrow$ & $\downarrow$ & $\downarrow$ & $\downarrow$ & $\downarrow$ & $\downarrow$ & $\downarrow$ & $\downarrow$ \\
\hline $\begin{array}{c}\text { Close Contact } \\
\mathrm{Hx}\end{array}$ & $\begin{array}{l}\text { Typical } \\
\text { Synd }\end{array}$ & $\begin{array}{l}\text { linical } \\
\text { ome }\end{array}$ & $\begin{array}{l}\text { Resic } \\
\text { Trav }\end{array}$ & $\begin{array}{l}\text { nce / } \\
\text { Risk }\end{array}$ & & & 495 & 1,32 & 61.5 & 0.16 & 3.3 & 0.41 & 150 & 0.4 & 1 \\
\hline \multirow{4}{*}{+} & \multirow{2}{*}{\multicolumn{2}{|c|}{+}} & \multicolumn{2}{|c|}{+} & $\rightarrow$ & 0.8 & 0.999 & 0.84 & 0.996 & 0.39 & 0.93 & 0.63 & 0.998 & 0.62 & 0.8 \\
\hline & & & \multicolumn{2}{|c|}{ - } & $\rightarrow$ & 0.7 & 0.999 & 0.76 & 0.993 & 0.27 & 0.89 & 0.49 & 0.997 & 0.48 & 0.7 \\
\hline & \multirow{2}{*}{\multicolumn{2}{|c|}{ - }} & \multicolumn{2}{|c|}{+} & $\rightarrow$ & 0.4 & 0.996 & 0.47 & 0.976 & 0.1 & 0.69 & 0.21 & 0.99 & 0.21 & 0.4 \\
\hline & & & & & $\rightarrow$ & 0.3 & 0.985 & 0.36 & 0.964 & 0.06 & 0.59 & 0.15 & 0.984 & 0.15 & 0.3 \\
\hline \multirow{4}{*}{-} & \multirow{2}{*}{\multicolumn{2}{|c|}{+}} & & & $\rightarrow$ & 0.35 & 0.996 & 0.42 & 0.97 & 0.08 & 0.64 & 0.18 & 0.988 & 0.18 & 0.35 \\
\hline & & & & & $\rightarrow$ & 0.2 & 0.991 & 0.25 & 0.94 & 0.04 & 0.45 & 0.09 & 0.97 & 0.09 & 0.2 \\
\hline & \multirow{2}{*}{\multicolumn{2}{|c|}{ - }} & & & $\rightarrow$ & 0.15 & 0.98 & 0.19 & 0.92 & 0.03 & 0.37 & 0.07 & 0.96 & 0.06 & 0.15 \\
\hline & & & & & $\rightarrow$ & 0.1 & 0.98 & 0.13 & 0.87 & 0.02 & 0.27 & 0.05 & 0.94 & 0.04 & 0.1 \\
\hline
\end{tabular}

Figure 1

probability of COVID-19 infection. 


\begin{tabular}{|c|c|c|c|c|}
\hline & Sn & Sp & LR+ & LR- \\
\hline CT & 66 & 80 & 3.3 & 0.41 \\
\hline RT-PCR & 0.6 & 99.6 & 150 & 0.4 \\
\hline
\end{tabular}

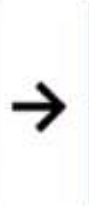

\begin{tabular}{c|c|c|c|c|c|c|c|c|c|}
\hline $\mathrm{CT}$ & + & + & - & - & + & - & NP & NP & NP \\
\hline RT-PCR & + & - & + & - & NP & NP & + & - & NP \\
\hline
\end{tabular}

\begin{tabular}{|c|c|c|}
\hline $\begin{array}{c}\text { Close Contact } \\
\mathrm{Hx}\end{array}$ & $\begin{array}{c}\text { Typical Clinical } \\
\text { Syndrome }\end{array}$ & $\begin{array}{l}\text { Residence / } \\
\text { Travel Risk }\end{array}$ \\
\hline \multirow{4}{*}{+} & \multirow{2}{*}{+} & + \\
\hline & & - \\
\hline & \multirow{2}{*}{ - } & + \\
\hline & & - \\
\hline \multirow{4}{*}{ - } & \multirow{2}{*}{+} & + \\
\hline & & - \\
\hline & \multirow{2}{*}{ - } & + \\
\hline & & - \\
\hline
\end{tabular}

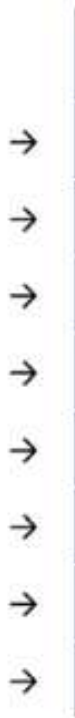
tikelihood Pretest Rabability

(4)

0.8

995

0.163

30.41

0.4115

\begin{tabular}{l|l}
150 & 0.4
\end{tabular}

1

\begin{tabular}{|c|}
\hline 0.8 \\
\hline 0.7
\end{tabular}

\begin{tabular}{|l|l|l|l|l|l|l|l|l|}
\hline 0.999 & 0.84 & 0.996 & 0.39 & 0.93 & 0.63 & 0.998 & 0.62 & 0.8 \\
\hline
\end{tabular}

0.4

\begin{tabular}{|l|l|l|l|l|l|l|l|l|}
\hline 0.999 & 0.76 & 0.993 & 0.27 & 0.89 & 0.49 & 0.997 & 0.48 & 0.7 \\
\hline
\end{tabular}

0.3

\begin{tabular}{|c|c|c|c|c|c|c|c|c|c|}
\hline $\mathbf{0 . 3 5}$ & 0.996 & 0.42 & 0.97 & 0.08 & 0.64 & 0.18 & 0.988 & 0.18 & 0.35 \\
\hline $\mathbf{0 . 2}$ & 0.991 & 0.25 & 0.94 & 0.04 & 0.45 & 0.09 & 0.97 & 0.09 & 0.2 \\
\hline $\mathbf{0 . 1 5}$ & 0.98 & 0.19 & 0.92 & 0.03 & 0.37 & 0.07 & 0.96 & 0.06 & 0.15 \\
\hline $\mathbf{0 . 1}$ & 0.98 & 0.13 & 0.87 & 0.02 & 0.27 & 0.05 & 0.94 & 0.04 & 0.1 \\
\hline
\end{tabular}

Post-test Probability

\begin{tabular}{|l|l|l|l|}
\hline Confirmed & Probable & Suspected & Improbable \\
\hline
\end{tabular}

Figure 2

classification of the probability of the covid-19 disease infection 


\begin{tabular}{|c|c|c|c|c|}
\hline & Sn & Sp & LR+ & LR- \\
\hline CT & 66 & 80 & 3.3 & 0.41 \\
\hline RT-PCR & 0.6 & 99.6 & 150 & 0.4 \\
\hline
\end{tabular}

\begin{tabular}{c|c|c|c|c|c|c|c|c|c|c|}
\hline $\mathrm{CT}$ & + & + & - & - & + & - & $\mathrm{NP}$ & $\mathrm{NP}$ & $\mathrm{NP}$ \\
\hline $\mathrm{RT}-\mathrm{PCR}$ & + & - & + & - & $\mathrm{NP}$ & $\mathrm{NP}$ & + & - & $\mathrm{NP}$ \\
\hline
\end{tabular}

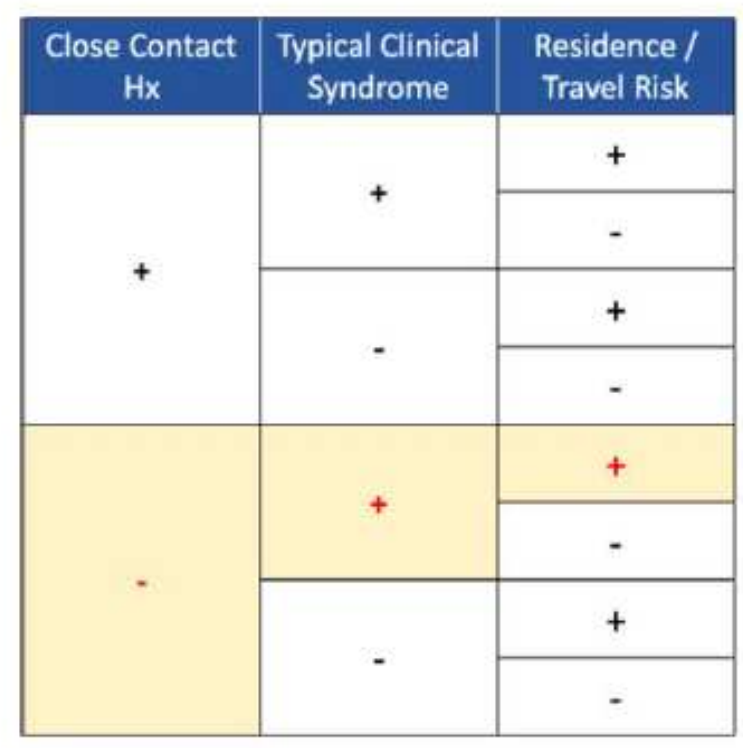

\begin{tabular}{|c|c|c|c|c|c|c|c|c|c|}
\hline $\begin{array}{l}\text { Uikelihood } \\
\text { Pretest Probability Ratio }\end{array}$ & 495 & 1.32 & 61.5 & 0.16 & 3.3 & 0.41 & 150 & 0.4 & 1 \\
\hline 0.8 & 0.999 & 0.84 & 0.996 & 0.39 & 0.93 & 0.63 & 0.998 & 0.62 & 0.8 \\
\hline 0.7 & 0.999 & 0.76 & 0.993 & 0.27 & 0.89 & 0.49 & 0.997 & 0.48 & 0.7 \\
\hline 0.4 & 0.996 & 0.47 & 0.976 & 0.1 & 0.69 & 0.21 & 0.99 & 0.21 & 0.4 \\
\hline 0.3 & 0.985 & 0.36 & 0.964 & 0.06 & 0.59 & 0.15 & 0.984 & 0.15 & 0.3 \\
\hline 0.35 & 0.996 & 0.42 & 0.97 & 0.08 & 0.64 & 0.18 & 0.988 & 0.18 & 0.35 \\
\hline 0.2 & 0.991 & 0.25 & 0.94 & 0.04 & 0.45 & 0.09 & 0.97 & 0.09 & 0.2 \\
\hline 0.15 & 0.98 & 0.19 & 0.92 & 0.03 & 0.37 & 0.07 & 0.96 & 0.06 & 0.15 \\
\hline 0.1 & 0.98 & 0.13 & 0.87 & 0.02 & 0.27 & 0.05 & 0.94 & 0.04 & 0.1 \\
\hline
\end{tabular}

\section{Figure 3}

Post-test probability for CT (- ), RT-PCR (NP), Close Contact (-), Symptom ( + ), Location ( + )

\begin{tabular}{|c|c|c|c|c|}
\hline & Sn & Sp & LR+ & LR- \\
\hline CT & 66 & 80 & 3.3 & 0.41 \\
\hline RT-PCR & 0.6 & 99.6 & 150 & 0.4 \\
\hline $\begin{array}{c}\text { Close Contact } \\
\mathrm{Hx}\end{array}$ & $\begin{array}{r}\text { Typict } \\
\text { Syn }\end{array}$ & $\begin{array}{l}\text { Clinical } \\
\text { ome }\end{array}$ & $\begin{array}{l}\text { Resi } \\
\text { Trai }\end{array}$ & $\begin{array}{l}\text { nce / } \\
\text { Risk }\end{array}$ \\
\hline \multirow{4}{*}{+} & \multirow{2}{*}{\multicolumn{2}{|c|}{+}} & \multicolumn{2}{|c|}{+} \\
\hline & & & \multicolumn{2}{|c|}{ - } \\
\hline & \multirow{2}{*}{\multicolumn{2}{|c|}{ - }} & \multicolumn{2}{|c|}{+} \\
\hline & & & & \\
\hline \multirow{4}{*}{ - } & \multirow{2}{*}{\multicolumn{2}{|c|}{+}} & \multicolumn{2}{|c|}{+} \\
\hline & & & \multicolumn{2}{|c|}{ - } \\
\hline & \multirow{2}{*}{\multicolumn{2}{|c|}{ - }} & \multicolumn{2}{|c|}{+} \\
\hline & & & \multicolumn{2}{|c|}{ - } \\
\hline
\end{tabular}

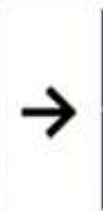

\begin{tabular}{|c|c|c|c|c|c|c|c|c|c|}
\hline $\mathrm{CT}$ & + & + & - & - & + & - & $\mathrm{NP}$ & $\mathrm{NP}$ & $\mathrm{NP}$ \\
\hline $\mathrm{RT}-\mathrm{PCR}$ & + & - & + & - & $\mathrm{NP}$ & $\mathrm{NP}$ & + & - & $\mathrm{NP}$ \\
\hline
\end{tabular}

$\downarrow \quad \downarrow \quad \downarrow \quad \downarrow \quad \downarrow \quad \downarrow \quad \downarrow \quad \downarrow \quad \downarrow \quad \downarrow$

\begin{tabular}{|c|c|c|c|c|c|c|c|c|c|}
\hline $\begin{array}{l}\text { Pretest Likelihood } \\
\text { Probability Ratio }\end{array}$ & 495 & 1.32 & 61.5 & 0.16 & 3.3 & 0.41 & 150 & 0.4 & 1 \\
\hline 0.8 & 0.999 & 0.84 & 0.996 & 0.39 & 0.93 & 0.63 & 0.998 & 0.62 & 0.8 \\
\hline 0.7 & 0.999 & 0.76 & 0.993 & 0.27 & 0.89 & 0.49 & 0.997 & 0.48 & 0.7 \\
\hline 0.4 & 0.996 & 0.47 & 0.976 & 0.1 & 0.69 & 0.21 & 0.99 & 0.21 & 0.4 \\
\hline 0.3 & 0.985 & 0.36 & 0.964 & 0.06 & 0.59 & 0.15 & 0.984 & 0.15 & 0.3 \\
\hline 0.35 & 0.996 & 0.42 & 0.97 & 0.08 & 0.64 & 0.18 & 0.988 & 0.18 & 0.35 \\
\hline 0.2 & 0.991 & 0.25 & 0.94 & 0.04 & 0.45 & 0,09 & 0.97 & 0.09 & 0.2 \\
\hline 0.15 & 0.98 & 0.19 & 0.92 & 0.03 & 0.37 & 0.07 & 0.96 & 0.06 & 0.15 \\
\hline 0.1 & 0.98 & 0.13 & 0,87 & 0.02 & 0.27 & 0.05 & 0.94 & 0.04 & 0.1 \\
\hline
\end{tabular}


Figure 4

Post-test probability for CT (-) , RT-PCR (+ ), Close Contact (-), Symptom (- ), Location (+ )

\begin{tabular}{|c|c|c|c|c|}
\hline & Sn & Sp & LR+ & LR- \\
\hline CT & 66 & 80 & 3.3 & 0.41 \\
\hline RT-PCR & 0.6 & 99.6 & 150 & 0.4 \\
\hline
\end{tabular}

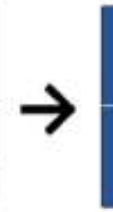

\begin{tabular}{|c|c|c|c|c|c|c|c|c|c|}
\hline $\mathrm{CT}$ & + & + & - & - & + & - & $\mathrm{NP}$ & $\mathrm{NP}$ & $\mathrm{NP}$ \\
\hline $\mathrm{RT}-\mathrm{PCR}$ & + & - & + & - & $\mathrm{NP}$ & $\mathrm{NP}$ & + & - & $\mathrm{NP}$ \\
\hline
\end{tabular}

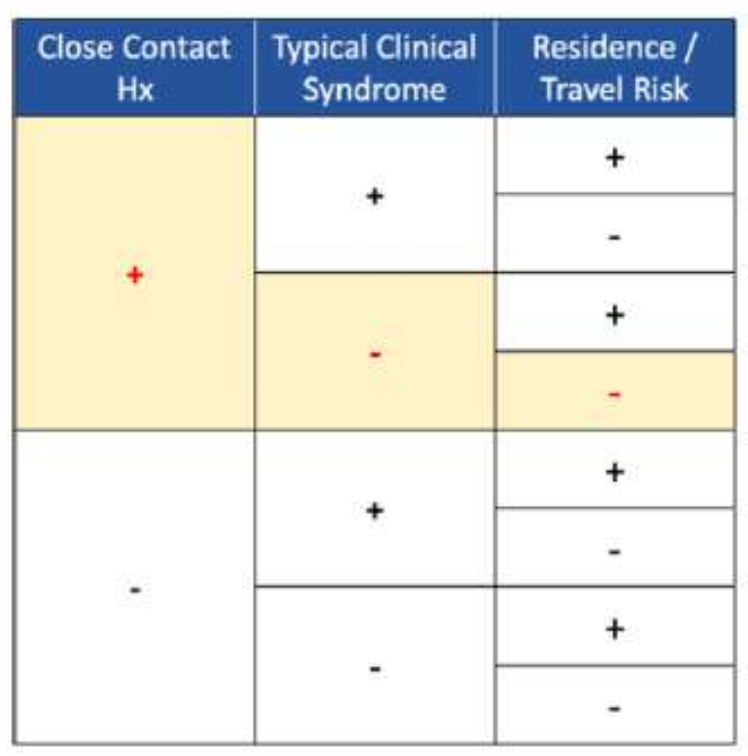

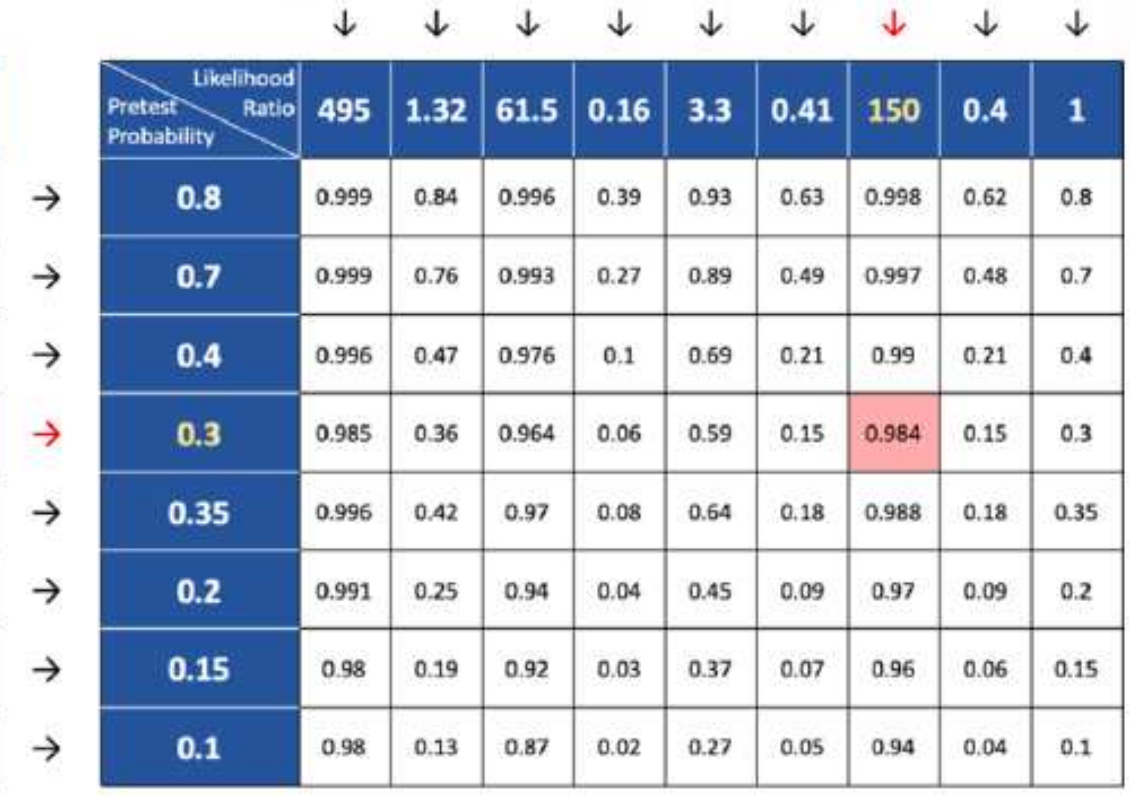

\section{Figure 5}

Post-test probability for CT ( NP), RT-PCR (+), Close Contact (+ ), Symptom (- ), Location (-) 